\title{
Article \\ The Renewable Hydrogen-Methane (RHYME) Transportation Fuel: A Practical First Step in the Realization of the Hydrogen Economy
}

\author{
John G. Ingersoll $\mathbb{D}$
}

Citation: Ingersoll, J.G. The Renewable Hydrogen-Methane (RHYME) Transportation Fuel: A Practical First Step in the Realization of the Hydrogen Economy. Hydrogen 2022, 3, 84-112. https://doi.org/ 10.3390/hydrogen3010008

Academic Editor: George E. Marnellos

Received: 15 December 2021

Accepted: 29 January 2022

Published: 18 February 2022

Publisher's Note: MDPI stays neutral with regard to jurisdictional claims in published maps and institutional affiliations.

Copyright: (C) 2022 by the author. Licensee MDPI, Basel, Switzerland. This article is an open access article distributed under the terms and conditions of the Creative Commons Attribution (CC BY) license (https:// creativecommons.org/licenses/by/ $4.0 /)$
ECOCORP Inc., Arlington, VA 22202, USA; jgingersoll@ecocorp.com; Tel.: +1-202-999-0840

\begin{abstract}
The permanent introduction of green hydrogen into the energy economy would require that a discriminating selection be made of its use in the sectors where its value is optimal in terms of relative cost and life cycle reduction in carbon dioxide emissions. Consequently, hydrogen can be used as an energy storage medium when intermittent wind and solar power exceed certain penetration in the grid, likely above $40 \%$, and in road transportation right away, to begin displacing gasoline and diesel fuels. To this end, the proposed approach is to utilize current technologies represented by PHEV in light-duty and HEV in heavy-duty vehicles, where a high-performance internal combustion engine is used with a fuel comprised of $15-20 \%$ green hydrogen and $85-89 \%$ green methane depending on vehicle type. This fuel, designated as RHYME, takes advantage of the best attributes of hydrogen and methane, results in lower life cycle carbon dioxide emissions than BEVs or FCEVs and offers a cost-effective and pragmatic approach, both locally as well as globally, in establishing hydrogen as part of the energy economy over the next ten to thirty years.
\end{abstract}

Keywords: renewable/green hydrogen; renewable/green methane; biomethane; water electrolysis; wind power; anaerobic digestion; organic wastes/energy crops; road transportation; PHEV; HEV; $\mathrm{BEV} ; \mathrm{FCEV}$

\section{Introduction}

The notion of hydrogen as a chemical fuel, energy carrier and energy storage medium appears to have started just about 200 years ago [1]. However, no practical use of hydrogen as a fuel commenced until the 1920s, when electrolysis was introduced as a commercial means of producing hydrogen from water with the objective of storing hydropower. In the 1930s, the concepts of hydrogen both as an automotive fuel as well as an energy carrier were introduced. Since that time and every twenty years or so, it would seem, intense activity on the introduction of hydrogen as a fuel and energy storage medium would emerge. Such activity would be prompted each time by a different set of circumstances and would subside a few years later. For example, the perceived shortage as well as uneven distribution of oil resources in the 1930s may have induced the use of hydrogen as a transportation fuel then. The development of the fuel cell as an alternative to the internal combustion engine along with the development of the space program may have prompted the 1950s revival of hydrogen as a fuel. In the 1970s, the energy crisis as well as environmental pollution catalyzed another hydrogen revival that also led to the introduction of the term "Hydrogen Economy" [2]. In the early 2000s, another hydrogen revival took place prompted by concerns about climate change. Now, in the 2020s, global warming is driving once more a hydrogen revival. It remains to be seen whether hydrogen as a fuel as well as an energy storage medium takes hold this time around. One major, if not the major, impediment is the cost associated with the replacement of the existing energy infrastructure, based traditionally on oil and now more than ever on natural gas, with a different energy system based on hydrogen. Such transition will span decades and requires among others, the correct pricing of the current fuels in terms of accounting for externalities such as health 
effects due to urban pollution, military cost of defending the supply of oil, and most important, the potential risk of climate change. Given these constrains for the introduction of hydrogen as a fuel, an incremental process is envisioned, whereby renewable hydrogen is introduced gradually in conjunction with biomethane in the transportation sector. This transition can occur along with the ongoing transition from oil to natural gas as the primary energy source. This article proceeds as follows: Section 2 considers the environmental and cost issues of three shades (grey, blue and green) of hydrogen; Section 3 considers, likewise, the environmental and cost issues of the three shades (grey, blue and green) of methane; Section 4 examines pathways for the adoption of green hydrogen; Section 5 introduces the RHYME fuel vis-à-vis other fuels; Section 6 reviews the RHYME fuel characteristics; Section 7 presents a potential scenario for the introduction of the RHYME fuel in the period over the next 10 to 30 years; and Section 8 concludes by addressing policy issues.

\section{Grey Hydrogen, Blue Hydrogen and Green Hydrogen}

Hydrogen is already in use in a multitude of functions globally. In 2020 some 90 million tons ( 1 billion cubic meters) were essentially employed in oil refining $(45 \%)$ and industrial uses comprised of ammonia production as a fertilizer (33\%), methanol production as a feedstock for chemicals (11\%) and in iron and steel manufacturing (11\%) [3]. A very small amount of hydrogen (less than $0.001 \%$ ) was used as a transportation fuel in conjunction with fuel cells. The current global demand for hydrogen is met from fossil fuels, primarily $(80 \%)$ the steam reforming of fossil natural gas and secondarily the gasification of coal and heavy oil, with less than $0.01 \%$ coming from renewable resources such as solar and wind power via electrolysis of water as well as biomethane via reformation. The resulting $\mathrm{CO}_{2}$ emissions from the current use of hydrogen are estimated to be about 900 million tons per year [3].

Conventional hydrogen produced from natural gas is classified as "grey" hydrogen to differentiate it from "brown" hydrogen produced from the gasification of coal. As indicated above, the production of one ton of hydrogen generates about 10 tons of carbon dioxide. However, detailed calculation of the carbon dioxide emission in the production of grey hydrogen indicates a value of $77 \mathrm{~g} \mathrm{CO}_{2} / \mathrm{MJ}$ of $\mathrm{H}_{2}$ or 11 tons of carbon dioxide per ton of hydrogen [4]. Thus, conventional hydrogen produced from fossil fuels is obviously not sustainable.

Consequently, the production of hydrogen from steam reforming of natural gas along with the simultaneous carbon capture and either use (CCU), storage (CCS) or both (CCUS) is advocated in Europe and the US as representing a sustainable process and resulting in a sustainable fuel $[3,5]$. Incidentally, hydrogen produced from natural gas with carbon capture is designated as "blue" hydrogen. The steam reforming of natural gas, i.e., essentially methane, is an endothermic reaction requiring the burning of natural gas (methane) to supply necessary energy (heat and pressure) for the reforming process. The required amount of additional methane to supply the reforming energy ranges from 2.0 to $2.5 \mathrm{kWh} / \mathrm{m}^{3}$ of hydrogen [6]. The overall process of steam methane reforming or SMR is given by Equation (1):

$$
\mathrm{CH}_{4}+\mathrm{H}_{2} \mathrm{O}+\{2.25 \mathrm{kWh} \mathrm{CH} \text { input energy }\} \rightarrow \mathrm{CO}_{2}+4 \mathrm{H}_{2}
$$

where we have used the average of the range for the energy use in the process. The gross calorific values of methane and hydrogen are $0.772 \mathrm{MJ} / \mathrm{mol}$ and $0.286 \mathrm{MJ} / \mathrm{mol}$, respectively. Based on Equation (1), it is straightforward to calculate the amount of methane used for the production of hydrogen as follows: 
Stochiometric conversion of $\mathrm{CH}_{4}$ to $\mathrm{H}_{2}$ :

$\left(1 \mathrm{~mol} \mathrm{CH}_{4} \times 0.888 \mathrm{MJ} / \mathrm{mol}\right) /\left(4 \mathrm{~mol} \mathrm{H}_{2}\right)=0.222 \mathrm{MJ} \mathrm{CH}_{4} / \mathrm{mol} \mathrm{H}_{2}$

with $2.25 \mathrm{kWh} \mathrm{CH}_{4}$ input as process energy:

$$
\begin{aligned}
& \left(2.25 \mathrm{kWh} \times 3.6 \mathrm{MJ} / \mathrm{kWh} \times\left(1 \mathrm{~m}^{3} \mathrm{H}_{2} / 1000 \mathrm{~L}\right) \times 22.4 \mathrm{~L} / \mathrm{mol} \mathrm{H}_{2}\right)= \\
& 0.181 \mathrm{MJ} \mathrm{CH}_{4} / \mathrm{mol} \mathrm{H}_{2}
\end{aligned}
$$

Thus, the production of hydrogen via steam reforming requires $0.403 \mathrm{MJ}$ of methane to produce one mole of hydrogen. The conversion efficiency of the SME process is: $0.286 \mathrm{MJ}$ $\mathrm{H}_{2} / 0.403 \mathrm{MJ} \mathrm{CH}_{4}=0.709$ or almost $71 \%$. Moreover, the split of energy use per Equations (2) and (3) of $55 \%$ and $45 \%$, respectively, suggests that the carbon dioxide is also emitted in a similar ratio. As of 2021, there are two large commercial facilities producing "blue" hydrogen from natural gas: one operated by Shell in Edmonton, Canada; and the other operated by Air Products in Port Arthur, Texas, TX, USA [7]. The limited available data regarding the percentage of carbon dioxide capture indicate a CCS rate ranging from a low of 53\% to a high of $90 \%$ [8]. The Shell plant in Alberta exhibits a similar CCS range with a mean capture efficiency of 78.8\% [9]. These efficiencies apply to the SMR proper per Equation (2). Apparently, no carbon dioxide is captured from the process energy used to drive the conversion. Hopefully, in the future, there could be a significant capture of that carbon dioxide as well, perhaps as much two-thirds of it [10]. Lastly, the CCS process requires additional energy in order to be carried out. This energy is also obtained via the combustion of natural gas. While hard data for the required energy and associated carbon dioxide emissions of the CCS are not readily available, a figure of $25 \%$ of the total energy and consequently of the total carbon dioxide emitted in the steam reforming of methane is proposed as being applicable [10-13]. Thus, the energy required for the CCS and the resulting carbon dioxide emissions will be as follows:

$$
\begin{aligned}
& \text { Energy use for CCS: } 0.25 \times 0.403 \mathrm{MJ} \mathrm{CH}_{4} / \mathrm{mol} \mathrm{H}_{2}=0.101 \mathrm{MJ} \mathrm{CH} / \mathrm{mol} \mathrm{H}_{2} \\
& \text { Carbon dioxide emission from CCS: } 0.25 \times 77 \mathrm{~g} / \mathrm{MJ} \mathrm{H} \mathrm{H}_{2}=19.3 \mathrm{~g} \mathrm{CO}_{2} / \mathrm{MJ} \mathrm{H}_{2}
\end{aligned}
$$

We summarize the calculated emissions of carbon dioxide for various scenarios of capture rates in Table 1. Regarding the carbon dioxide capture, we have assumed an $85 \%$ rate for the SMR process per Equation (2), a $65 \%$ rate for the process energy used per Equation (4) and no capture for the energy used for the CCS. These capture rate figures are quite optimistic and the decreasing rate is due to the lower concentration of carbon dioxide of the subprocesses described by Equations (2) to (4) [14]. We also note that the conversion efficiency of methane into blue hydrogen via SMR with CCS is equal to $0.286 \mathrm{MJ} \mathrm{H}_{2} / 0.504 \mathrm{MJ} \mathrm{CH}_{4}=0.567$. This result suggests that more than $40 \%$ of the energy in the converted methane is lost during the process of obtaining blue hydrogen with CSS. Moreover, the emissions of carbon dioxide for blue hydrogen are reduced by $51 \%$ from those of grey hydrogen, i.e., better than a factor of two. 
Table 1. Energy use and carbon dioxide emissions for the production of one megajoule of either grey or blue hydrogen from methane and of green hydrogen from water and wind power.

\begin{tabular}{|c|c|c|c|}
\hline Parameter-Units & Grey $\mathrm{H}_{2}$ & Blue $\mathrm{H}_{2}$ & Green $\mathrm{H}_{2}$ \\
\hline Hydrogen produced MJ & 1.000 & 1.000 & 1.000 \\
\hline \multicolumn{4}{|l|}{ SMR process } \\
\hline $\mathrm{CH}_{4}$ used, g/MJ & $14.0 / 0.770$ & $14.0 \mathrm{~g} / 0.770$ & $\mathrm{n} / \mathrm{a}$ \\
\hline $\mathrm{CO}_{2}$ emitted, $\mathrm{g}$ & 42.35 & 42.35 & $\mathrm{n} / \mathrm{a}$ \\
\hline $\mathrm{CO}_{2}$ capture rate, $\%$ & 0 & 85 & $\mathrm{n} / \mathrm{a}$ \\
\hline \multicolumn{4}{|l|}{ Energy for SMR process } \\
\hline $\mathrm{CH}_{4}$ used, $\mathrm{g} / \mathrm{MJ}$ & $11.4 / 0.633$ & $11.4 / 0.633$ & $\mathrm{n} / \mathrm{a}$ \\
\hline $\mathrm{CO}_{2}$ emitted, $\mathrm{g}$ & 34.65 & 34.65 & $\mathrm{n} / \mathrm{a}$ \\
\hline $\mathrm{CO}_{2}$ capture rate, $\%$ & 0 & 65 & $\mathrm{n} / \mathrm{a}$ \\
\hline \multicolumn{4}{|l|}{ Energy for $\mathrm{CO}_{2}$ capture } \\
\hline $\mathrm{CH}_{4}$ used, $\mathrm{g} / \mathrm{MJ}$ & 0 & $6.4 / 0.355$ & $\mathrm{n} / \mathrm{a}$ \\
\hline $\mathrm{CO}_{2}$ emitted, $\mathrm{g}$ & 0 & 19.3 & $\mathrm{n} / \mathrm{a}$ \\
\hline \multicolumn{4}{|l|}{ Electrolysis } \\
\hline Wind used, kWh/MJ & $\mathrm{n} / \mathrm{a}$ & $\mathrm{n} / \mathrm{a}$ & \\
\hline $\mathrm{CO}_{2}$ produced & $\mathrm{n} / \mathrm{a}$ & $\mathrm{n} / \mathrm{a}$ & \\
\hline Total $\mathrm{CH}_{4}$ used, $\mathrm{g} / \mathrm{MJ}$ & $25.4 / 1.403$ & $31.8 / 1.758$ & $\mathrm{n} / \mathrm{a}$ \\
\hline Total wind used, $\mathrm{kWh} / \mathrm{MJ}$ & $\mathrm{n} / \mathrm{a}$ & $\mathrm{n} / \mathrm{a}$ & 0.092 \\
\hline Total process efficiency, \% & 0.713 & 0.569 & 0.867 \\
\hline Total $\mathrm{CO}_{2}$ emitted, $\mathrm{g}$ & 77.00 & 37.78 & 3.53 \\
\hline
\end{tabular}

Blue hydrogen shows a significant environmental improvement with respect to grey hydrogen under admittedly quite optimistic assumptions for CCS, but it is still resulting in an emission of about 5 million tons of carbon dioxide per 1 million tons of hydrogen produced. Thus, there will be a need for "green" hydrogen ultimately, which is produced from renewable energy exclusively, with essentially minimal carbon dioxide emissions. Green hydrogen would be the one that is envisioned to be an energy carrier in the global economy, if the concept of the hydrogen economy were to become a reality. While any renewable energy can be used for the production of hydrogen, intermittent sources such as wind, solar and hydropower can be used to that end, whereby hydrogen serves as a storage medium for these renewable resources. Historically, the need to store hydropower some one hundred years ago led to the commercialization of electrolysis for the production of hydrogen. However, the magnitude of the hydropower resource is not sufficient to act as the energy source for a universal hydrogen economy. Moreover, the use of biomethane produced via anaerobic digestion of organic wastes, energy crops and biomass in general to generate hydrogen via SMR is redundant and not necessary, given that biomethane is also an energy carrier in its own right as a fuel. Thus, solar and wind are the two natural renewable energy sources for the production of hydrogen. Both are abundant. However, based on the respective occurrence patterns of solar energy (horizontal capture) and of wind energy (vertical capture) on land and along coastal areas and the associated technologies for the generation of electricity, solar energy appears to be more suitable in general for powering buildings, particularly in urban areas, and for supplying power to utilities for the use of their customers. Wind, on the other hand, can serve as the main source of energy for the production of hydrogen in rural and relatively remote areas. Historically, wind has been associated with hydrogen at a large scale. In the 1930s, one of the pioneers of hydrogen as the fuel of the future, namely, Hermann Honnef in Germany, envisioned huge wind turbines $480 \mathrm{~m}$ in height with a $450 \mathrm{~m}$ rotor diameter and $100 \mathrm{MW}$ of power as being the means of production of hydrogen via electrolysis [1]. It would take at least 70 years before wind turbines in the megawatt size would become available. Moreover, while 100 MW wind turbines may never become practical, wind turbines at $15 \mathrm{MW}$ are already being commercialized $[15,16]$. The water electrolysis technology has also advanced greatly in the past one hundred years [17]. Although the standard potassium hydroxide $(\mathrm{KOH})$ electrolysis remains the technology of choice in large hydrogen production applications, proton exchange membranes (PEM), phosphoric acid $\left(\mathrm{H}_{3} \mathrm{PO}_{4}\right)$ and solid oxide (SO) electrolytes 
are also available in different stages of maturity and cost. Individual electrolysis units with a nominal capacity of $4000 \mathrm{Nm}^{3} / \mathrm{h}$ of hydrogen are commercially available and hydrogen plants exceeding 30,000 $\mathrm{Nm}^{3} / \mathrm{h}$ output and $60 \mathrm{MW}$ input are already in operation [18]. Typical conversion efficiencies of alkaline electrolysis units range from $3.8 \mathrm{kWh} / \mathrm{Nm}^{3}$ to $4.4 \mathrm{kWh} / \mathrm{Nm}^{3}[17,18]$. Taking as an average efficiency $4.1 \mathrm{kWh} / \mathrm{Nm}^{3}$, the calculated wind energy required per megajoule of hydrogen would be:

$$
4.1 \mathrm{kWh} / \mathrm{m}^{3} \times 3.6 \mathrm{MJ} / \mathrm{kWh} \times 1 \mathrm{~m}^{3} / 1000 \mathrm{~L} \times 22.4 \mathrm{~L} / \mathrm{mol}=0.330 \mathrm{MJ} \text { wind } / \mathrm{mol} \mathrm{H}_{2}
$$

Since one mole of hydrogen contains $0.286 \mathrm{MJ}$, the conversion efficiency, which is essentially the efficiency of the electrolysis unit, is $0.286 \mathrm{MJ} \mathrm{H}_{2} / 0.330 \mathrm{MJ}$ wind $=0.866$. The carbon dioxide emissions from wind power have been calculated in several studies. While the actual generation of wind power does not emit any carbon dioxide, the manufacture and installation of wind turbines requires, among others, large quantities of steel, concrete and fiberglass. Because wind power carbon emissions are occurring upfront, i.e., before a turbine begins producing any power, these emissions are accounted for in the so-called life cycle analysis (LCA) and are calculated on a per generated kilowatt hour basis over the life of the turbine [19]. Thus, the reported LCA carbon dioxide emissions figure is $11 \mathrm{~g} / \mathrm{kWh}$ for the average fleet of wind turbines in operation. This figure is reduced to $6 \mathrm{~g} / \mathrm{kWh}$ for the $15 \mathrm{MW}$ wind turbines that are just starting to be commercialized. Incidentally, the same report indicates that solar photovoltaic power has a carbon dioxide emissions footprint four times as much at $44 \mathrm{~g} / \mathrm{kWh}$. Since $1 \mathrm{MJ}$ of hydrogen requires $0.330 \mathrm{MJ}$ wind $/ \mathrm{mol} \mathrm{H}_{2}$ $\times 3.5 \mathrm{~mol} \mathrm{H}_{2} / \mathrm{MJ} \mathrm{H}_{2}=1.155 \mathrm{MJ}$ wind $/ \mathrm{MJ} \mathrm{H}_{2}$, the carbon dioxide emissions of wind power per megajoule of hydrogen produced are thus calculated to be:

Carbon dioxide emission of wind power:

$$
1.155 \mathrm{MJ} /(3.6 \mathrm{MJ} / \mathrm{kWh}) \times 11 \mathrm{~g} / \mathrm{kWh}=3.529 \mathrm{~g} / \mathrm{MJ}
$$

These results regarding green hydrogen are also shown in Table 1 . We note that the green hydrogen carbon dioxide emissions are $1 / 20$ or $5 \%$ of those of grey hydrogen and $1 / 10$ or $10 \%$ of those of blue hydrogen. We also note that, as the size of wind turbines increases in the tens of megawatts rated capacity, carbon dioxide emissions have the potential to decrease by as much as a factor of two compared to the numbers shown in Table 1. Lastly, wind power employed for the production of green hydrogen represents a significantly better choice than solar photovoltaic energy in terms of life $\mathrm{CO}_{2}$ emissions.

The preceded analysis clearly shows that green hydrogen is the only choice, if hydrogen is going to become a universal energy carrier at some point in the future. However, green hydrogen is quite expensive to produce compared to the current alternatives of oil and natural gas. The cost for the production of green hydrogen in Europe currently ranges between EUR 2.5 and EUR 5.5/ kg [20]. Taking the mean of this cost range, we calculate the cost of green hydrogen to be about USD 0.0336/MJ (the exchange rate of EUR $1=$ USD 1.2 is used throughout). By comparison the city gate price of natural gas in the US averaged in 2020 about USD 3.2/GJ or USD 0.0032/MJ [21]. Thus, green hydrogen is roughly a factor of ten more expensive than natural gas. The cost of green hydrogen is driven essentially by the cost of renewable electricity and the cost of the electrolysis units.

The cost of renewable electricity is well established by numerous studies. Thus, the levelized cost of renewable electricity in Germany from a variety of sources according to a study published in 2018 by the Fraunhofer Institute for Solar Energy Systems (Fraunhofer-ISE) is reproduced in Figure 1 [22]. Wind power has a mean cost of about EUR 61/MWh for onshore generation and about EUR 106/MWh for offshore generation. An updated study for 2021 showed no change in the production cost of onshore wind but a reduction of the average cost of the offshore wind generation to about $€ 97 / \mathrm{MWh}$ [23]. The International Renewable Energy Agency (IRENA) reported in 2020 that the cost of wind electricity per megawatt hour stood at about USD 40 for onshore and about USD 80 for offshore generation [24]. The U.S. Energy Information Administration projects that by 
2026 onshore wind cost will be about USD 31/MWh and offshore wind cost will be USD 115/MWh (as of 2021 there were no offshore wind installations in the USA) [25]. The trend in the cost of wind power shown in these studies suggest that by 2030 , the cost of onshore wind power could be as low as one-half of what it is today.

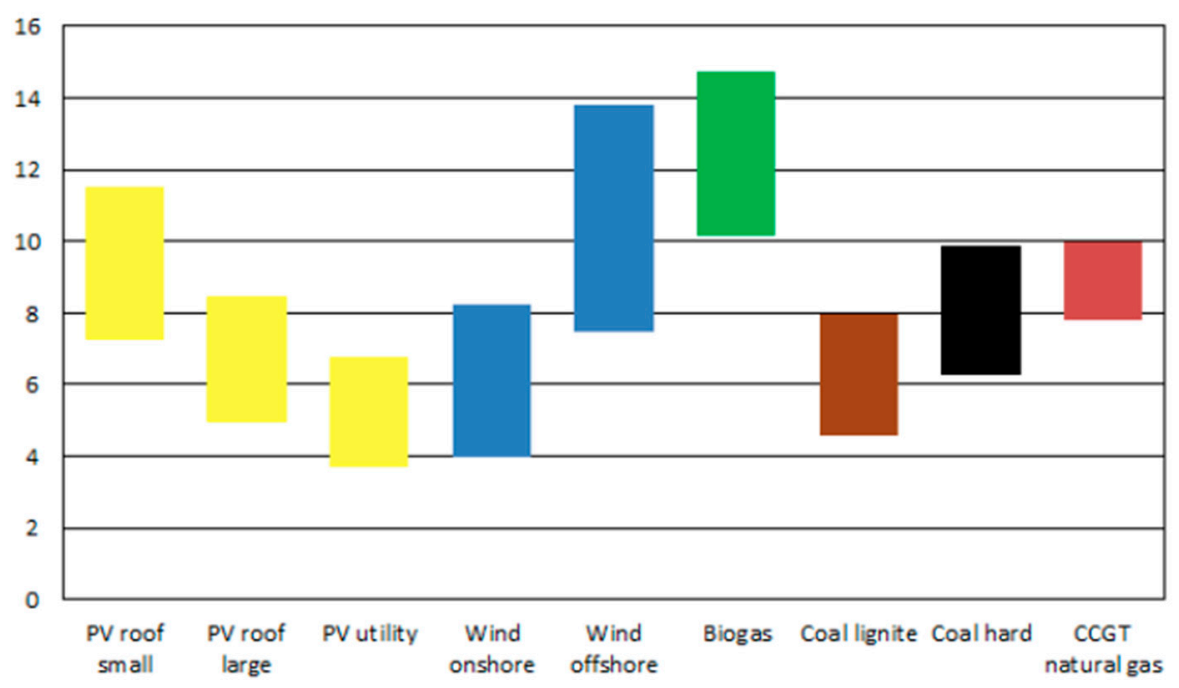

Figure 1. Levelized cost of electricity generation in Germany in eurocent per kWh in 2018 (source: Fraunhoffer-ISE [22]).

The cost of water electrolysis units has also been falling fast at a rate of $20 \%$ per doubling capacity [21]. At the moment, the 11 largest hydrogen production via electrolysis projects under construction and/or expansion range in capacity from $200 \mathrm{MW}$ to $11 \mathrm{MW}$ [26]. These projects with a total capacity of $756 \mathrm{MW}$ are expected to be completed by 2025 . The largest of these projects with a capacity of $200 \mathrm{MW}$ is located in the UAE. Three of these projects with a total capacity of $380 \mathrm{MW}$ are located in Germany, while the EU accounts cumulatively for $480 \mathrm{MW}$. The EU hydrogen strategy is to reduce the current cost of electrolysis units from EUR900/kW to EUR 450/kW by 2030 [20]. This will require increasing the 2020 capacity by almost a factor of ten in this decade. The current EU plans are to have $1.3 \mathrm{GW}$ of electrolysis capacity associated with refineries and $0.7 \mathrm{GW}$ of capacity associated with merchant use by 2025, and $40 \mathrm{GW}$ of capacity of electrolysis plants by 2030 [3,20]. Incidentally, based on results reported by the industry, $1 \mathrm{MW}$ of power generates $200 \mathrm{Nm}^{3} / \mathrm{h}$ and the annual operational capacity of the average current electrolysis plan is about $86 \%$ or $7500 \mathrm{~h}$ per year such that a $1 \mathrm{MW}$ electrolysis unit will generate annually 1.5 million cubic meters or about 150 tons of hydrogen $[3,18]$. Thus, the replacement of just the current global consumption of grey and brown hydrogen with green hydrogen would require $600 \mathrm{GW}$ of electrolysis units at a cost of USD 120 billion, considering an ultimate price of electrolysis units at USD 200/kW [20]. The required wind power would be about $1800 \mathrm{GW}$ with a cost of USD 2.7 trillion for onshore power priced at USD $1500 / \mathrm{kW}$.

The preceding analysis suggests that the average cost of green hydrogen may be reduced by a factor of two by 2030 to USD $0.017 /$ MJ. However, the required targets that must be met in terms of installed electrolysis units and associated wind along with even solar power are unlikely to be met with the current rate of development [3,20]. On the other hand, the cost of blue hydrogen is estimated to be EUR 2/kg or USD 0.017/MJ in Europe [20]. It is likely that the cost of blue hydrogen in the USA is one half of the EU cost figure given that the price of natural gas in the USA is two to three times lower than that in Europe. Therefore, in the foreseeable future, i.e., at least in the next ten years and perhaps longer, green hydrogen cannot compete with blue hydrogen on economic terms. 


\section{Grey Methane, Blue Methane and Green Methane}

Blue hydrogen, as we have already discussed, is not a sustainable fuel and consequently cannot become the energy carrier in a hydrogen economy. From a practical point of view, both in terms of emissions and cost, the direct use of methane or natural gas is a far better choice. In analogy to the hydrogen classification, we can distinguish grey methane, which is essentially fossil natural gas, blue methane, which is methane with some capture of carbon dioxide, and green methane, which is biomethane produced via the anaerobic digestion of organic wastes and energy crops. The carbon dioxide emissions of methane can be calculated from the combustion of one mole of methane generating one mole of carbon dioxide. Since one mole of methane contains $0.888 \mathrm{MJ}$ of energy or $1.126 \mathrm{~mol} / \mathrm{MJ}$, we have:

$$
\begin{aligned}
& \text { Carbon dioxide emission of methane: } \\
& 44 \mathrm{~g} \mathrm{CO}_{2} / \mathrm{mol} \mathrm{CH}_{4} \times 1.126 \mathrm{~mol} / \mathrm{MJ}=49.55 \mathrm{~g} / \mathrm{MJ} \mathrm{CH}_{4}
\end{aligned}
$$

Thus, the direct utilization of fossil or grey methane generates 1.31 times the carbon dioxide emissions of blue hydrogen, but only 0.643 times or $64.3 \%$ the carbon dioxide emissions of grey hydrogen. Applying a conservative and realistic $75 \%$ CCS for the blue methane and assuming as before that the energy use for the CCS is $25 \%$ of the grey methane energy used in the process, we have for the energy use and carbon dioxide emission of blue methane:

$$
\text { Energy use for CCS: } 0.25 \times 0.888 \mathrm{MJ} / \mathrm{mol} \mathrm{CH}_{4}=0.222 \mathrm{MJ} \mathrm{CH}_{4} / \mathrm{mol} \mathrm{CH}_{4}
$$

$$
\text { Carbon dioxide emission from CCS: } 0.25 \times 49.55 \mathrm{~g} / \mathrm{MJ} \mathrm{CH}_{4}=12.4 \mathrm{~g} \mathrm{CO}_{2} / \mathrm{MJ} \mathrm{CH}_{4}
$$

Green methane or biomethane is produced from organic wastes as well as energy crops via anaerobic digestion (AD) and is a well-established technology [27]. The AD process generates biogas, which is typically a mixture of $60 \%$ methane and $40 \%$ carbon dioxide by volume. The biogas is then separated into its components via a number of commercially available technologies with a recovery rate of up to $99 \%$ for the methane [28]. The carbon dioxide can be captured via liquefaction and be used as an industrial gas as green carbon dioxide in lieu of the current grey carbon dioxide derived from the combustion of natural gas [29]. Moreover, the carbon dioxide rejected from the upgrading of the biogas to methane can be utilized in two additional ways, both of which recycle it into the global environmental system. The first way is designated as "Green Methane from Green Hydrogen" and entails the use of the separated carbon dioxide from the biogas to react it with green hydrogen via a biological methanation process to convert it to additional methane according to the reaction:

$$
4 \mathrm{H}_{2}+\mathrm{CO}_{2} \rightarrow \mathrm{CH}_{4}+2 \mathrm{H}_{2} \mathrm{O}
$$

The green hydrogen and the carbon dioxide are introduced into an anaerobic trickle bed reactor operating at a thermophilic temperature of $55^{\circ} \mathrm{C}$. Hydrogenothrophic archaea predominated by Methanothermobacter thermoautotrophicuc convert almost $99 \%$ of the carbon dioxide into higher than $98 \%$ methane gas output [30,31]. The biological conversion of the carbon dioxide with green hydrogen into green methane is offered commercially [32]. One commercial facility is already in operation in Denmark and a proposal for its large-scale application in the USA has been made in conjunction with the conversion of waste wood into green methane [33]. Based on Equation (11) one ton of carbon dioxide will require $182 \mathrm{~kg}$ of hydrogen to generate $363 \mathrm{~kg}$ of methane. The second way is designated as "Green Methane from Microalgae" and entails the use of the carbon dioxide to grow microalgae, which are in turn harvested and converted via AD to obtain biogas [34]. The biogas is then separated into green methane and carbon dioxide which is recycled in the same fashion. The concept of growing algae has been around for some time, is quite efficient in capturing over $90 \%$ and potentially up to $99 \%$ of the carbon dioxide in open ponds, but it requires large surface areas in temperate climates and the generated biomass is very wet, i.e., less 
than $5 \%$ total solids. It is estimated that one ton of carbon dioxide can generate about 0.55 tons of dry biomass and would require a surface area of about $10 \mathrm{~m}^{2}$ for cultivation.

Returning to the upgrading of biogas, a three-stage membrane separation of the methane in the biogas with the concurrent liquefaction of the carbon dioxide is already offered commercially [35]. The carbon dioxide emissions of green or renewable methane can vary depending on the feedstock used in the process from $-264 \mathrm{~g} \mathrm{CO}_{2} / \mathrm{MJ} \mathrm{CH}_{4}$ from livestock manure to a high of $19 \mathrm{~g} \mathrm{CO}_{2} / \mathrm{MJ} \mathrm{CH}_{4}$ from sewage sludge [36-38]. We will use an average of $-6 \mathrm{~g} \mathrm{CO}_{2} / \mathrm{MJ}$ of $\mathrm{CH}_{4}$ from energy crops, which could become the norm after all organic wastes have been used up. The rate of capture and liquefaction of the $\mathrm{CO}_{2}$ in the biogas could be as high as $98 \%$, and the energy used for the liquefaction is conservatively $0.124 \mathrm{kWh} / \mathrm{kg} \mathrm{CO} 2$ or $0.446 \mathrm{MJ} / \mathrm{kg}[28,39]$. We also note that biogas contains on average $40 \%$ carbon dioxide by volume. Thus, in every normal cubic meter of biogas there will $0.4302 \mathrm{~kg}\left(0.6 \mathrm{~m}^{3} \times 0.717 \mathrm{~kg} / \mathrm{m}^{3}\right)$ of methane and $0.7908 \mathrm{~kg}\left(0.4 \mathrm{~m}^{3} \times 1.997 \mathrm{~kg} / \mathrm{m}^{3}\right)$ of carbon dioxide. This ratio indicates that for every mole of methane produced there will be $16 \mathrm{~g} \times(0.7908 / 0.4302)=29.411 \mathrm{~g}$ of carbon dioxide generated. The $\mathrm{CO}_{2}$ capture and liquefaction removes $29.411 \times 0.98 \mathrm{~g}=28.82 \mathrm{~g} \mathrm{CO}_{2} / \mathrm{mol} \mathrm{CH}_{4}$. The $\mathrm{CO}_{2}$ captured and the wind energy for $\mathrm{CO}_{2}$ liquefaction per $\mathrm{MJ}$ of $\mathrm{CH}_{4}$ produced are:

$$
\mathrm{CO}_{2} \text { liquefied/captured: } 28.82 \mathrm{~g} / \mathrm{mol} \times 1.126 \mathrm{~mol} / \mathrm{MJ}=32.45 \mathrm{~g} / \mathrm{MJ} \mathrm{CH}_{4}
$$

Energy use for $\mathrm{CO}_{2}$ liquefaction: $32.45 \mathrm{~g} \times 0.446 \mathrm{MJ} / \mathrm{kg}=0.0145 \mathrm{MJ} / \mathrm{MJ} \mathrm{CH}_{4}$

The liquefaction of carbon dioxide uses about $1.5 \%$ of the energy in the produced methane. The $\mathrm{CO}_{2}$ emissions from grey methane, blue methane and green methane, without and with the capture of the carbon dioxide in the biogas, are summarized in Table 2 . We may also note that if the $\mathrm{CO}_{2}$ in the biogas is reacted with hydrogen to produce more methane, we will have the following results per original megajoule of $\mathrm{CH}_{4}$ produced:

$$
\begin{gathered}
\qquad \mathrm{CH}_{4} \text { produced from captured } \mathrm{CO}_{2}: \\
32.45 \mathrm{~g} \times 16 \mathrm{~g} \mathrm{CH}_{4} / 44 \mathrm{~g} \mathrm{CO}_{2}=11.80 \mathrm{~g} / \mathrm{MJ} \mathrm{CH}_{4} \\
\mathrm{H}_{2} \text { required: } 32.45 \mathrm{~g} \times 4 \mathrm{~mol} \mathrm{H} / \mathrm{mol} \mathrm{CO}=5.90 \mathrm{~g} / \mathrm{MJ} \mathrm{CH}_{4} \\
\text { Wind power in: } 5.90 \mathrm{~g} \mathrm{H} \mathrm{H}_{2} \times 0.092 \mathrm{kWh} / \mathrm{mol} \times 0.5 \mathrm{~mol} / \mathrm{g}=0.271 \mathrm{kWh} / \mathrm{MJ} \mathrm{CH} \\
\text { Additional } \mathrm{CH}_{4} \text { energy production: } 11.80 \mathrm{~g} \times 0.888 \mathrm{MJ} / \mathrm{mol}=0.655 \mathrm{MJ} / \mathrm{MJ} \mathrm{CH} 4 \\
\text { Additional } \mathrm{CH}_{4} \text { production process efficiency: } 0.655 \mathrm{MJ} /(0.271 \times 3.6 \mathrm{MJ})=0.671
\end{gathered}
$$

The results for the production of additional methane from the carbon dioxide in the initial biogas are also summarized in Table 2 . We note that the energy efficiency of the entire process is higher than $100 \%$ due to the use of wind power to create more methane. Moreover, the total carbon dioxide emissions for the production of $1.655 \mathrm{MJ}$ of green methane stand at $-35.47 \mathrm{~g}$. This translates to $-35.46 / 1.655 \mathrm{~g}=-21.43 \mathrm{~g}$ of $\mathrm{CO}_{2}$ per megajoule of methane.

The difference in the results in Table 2 compared to those in Table 1 can be explained on the basis of the following facts. First, hydrogen is not a primary energy source, is derived from other primary sources such as methane and wind power and serves as an energy carrier, although there is some evidence of seepage of "natural" hydrogen from rock formations [40]. Second, biomethane depending on the feedstock materials from which it is derived can have negative carbon dioxide emissions, because the feedstock materials such as biomass contain carbon captured during photosynthesis that is then converted in part to methane and in part to carbon dioxide via anaerobic digestion. Third, the low energy use for the capture via liquefaction of the carbon dioxide in the biogas is due to the fact that the biogas upgrading process rejects essentially pure carbon dioxide. Fourth, the utilization of the carbon dioxide in the biogas with green hydrogen to produce more green methane results in an overall conversion efficiency over $100 \%$ because of wind power use and in even more negative carbon dioxide emissions. 
Table 2. Energy use and carbon dioxide emissions from the utilization/production of one megajoule of either grey methane or blue methane or green methane without biogas carbon dioxide capture, green methane with biogas carbon dioxide capture and green methane with biogas carbon dioxide utilization along with green hydrogen to generate more green methane.

\begin{tabular}{|c|c|c|c|c|c|}
\hline \multirow[b]{2}{*}{ Parameter-Units } & \multirow{2}{*}{$\begin{array}{l}\text { Grey } \\
\mathrm{CH}_{4}\end{array}$} & \multirow[b]{2}{*}{ Blue $\mathrm{CH}_{4}$} & \multicolumn{3}{|c|}{ Green $\mathrm{CH}_{4}$} \\
\hline & & & $\begin{array}{l}\text { Without } \\
\mathrm{CO}_{2} \text { cap. }\end{array}$ & $\begin{array}{l}\text { With } \\
\mathrm{CO}_{2} \text { cap. }\end{array}$ & $\begin{array}{l}\text { With } \\
\mathrm{CO}_{2}+\mathrm{H}_{2}\end{array}$ \\
\hline $\begin{array}{l}\text { Methane delivered, MJ } \\
\text { Utilization }\end{array}$ & 1.000 & 1.000 & 1.000 & 1.000 & 1.655 \\
\hline $\mathrm{CO}_{2}$ emitted, $\mathrm{g}$ & 49.55 & 49.55 & -6.00 & -6.00 & -6.00 \\
\hline $\mathrm{CO}_{2}$ capture rate, $\%$ & 0 & 75 & 0 & 98 & 98 \\
\hline $\begin{array}{l}\mathrm{CO}_{2} \text { net emission } \\
\text { Energy for } \mathrm{CO}_{2} \text { capture }\end{array}$ & 49.55 & 12.39 & -6.00 & -32.45 & -32.45 \\
\hline $\mathrm{CH}_{4}$ used, $\mathrm{g} / \mathrm{MJ}$ & 0 & 4.55 & 0 & 0 & $\mathrm{n} / \mathrm{a}$ \\
\hline Wind energy, kWh/MJ & $\mathrm{n} / \mathrm{a}$ & $\mathrm{n} / \mathrm{a}$ & $\mathrm{n} / \mathrm{a}$ & 0.043 & $\mathrm{n} / \mathrm{a}$ \\
\hline $\begin{array}{l}\mathrm{CO}_{2} \text { emitted, } \mathrm{g} \\
\text { Energy for } \mathrm{H}_{2} \text { production }\end{array}$ & 0 & 12.39 & 0 & 0.47 & $\mathrm{n} / \mathrm{a}$ \\
\hline $\mathrm{CO}_{2}$ utilized & $\mathrm{n} / \mathrm{a}$ & $\mathrm{n} / \mathrm{a}$ & $\mathrm{n} / \mathrm{a}$ & $\mathrm{n} / \mathrm{a}$ & 32.45 \\
\hline Wind energy, kWh & $\mathrm{n} / \mathrm{a}$ & $\mathrm{n} / \mathrm{a}$ & $\mathrm{n} / \mathrm{a}$ & $\mathrm{n} / \mathrm{a}$ & 0.271 \\
\hline Hydrogen used, g & $\mathrm{n} / \mathrm{a}$ & $\mathrm{n} / \mathrm{a}$ & $\mathrm{n} / \mathrm{a}$ & $\mathrm{n} / \mathrm{a}$ & 5.90 \\
\hline $\mathrm{CO}_{2}$ emitted, $\mathrm{g}$ & $\mathrm{n} / \mathrm{a}$ & $\mathrm{n} / \mathrm{a}$ & $\mathrm{n} / \mathrm{a}$ & $\mathrm{n} / \mathrm{a}$ & 2.98 \\
\hline Total $\mathrm{CH}_{4}$ used, $\mathrm{g} / \mathrm{MJ}$ & $18.02 / 1.000$ & $22.7 / 1.253$ & 0 & 0 & 0 \\
\hline Total process Efficiency, \% & 100.00 & 0.798 & 100.00 & 0.984 & 1.696 \\
\hline Total $\mathrm{CO}_{2}$ emitted, $\mathrm{g}$ & 49.55 & 24.78 & -6 & -37.97 & -35.47 \\
\hline
\end{tabular}

Note: it is assumed that $100 \%$ of the carbon dioxide is reacted with hydrogen to produce the additional green methane.

The cost of the production of biomethane varies with the feedstock materials as well as the magnitude of production [28]. Assuming large installations with a production of biogas of $2000 \mathrm{Nm}^{3} / \mathrm{h}$, we have the following average cost values for biomethane: production of biomethane at USD $0.305 / \mathrm{Nm}^{3}$ from animal manures and industrial wastes and twice as much from animal crops; upgrading at USD $0.125 / \mathrm{m}^{3}$; transmission via pipeline, including the interconnection cost at USD $0.1 / \mathrm{m}^{3}$. Thus, the average price of biomethane supplied to the market is on the order of USD $0.530 / \mathrm{m}^{3}$ for organic wastes to USD $0.835 / \mathrm{m}^{3}$ for energy crops. Figure 2 shows a detailed set of costs associated with biomethane production, upgrading and transmission [28]. We may also note that the cost of the carbon dioxide liquefaction employing wind power averages about EUR 6.7/ton for large facilities [39].

A comparison of the costs of green hydrogen (GM), green methane or biomethane without (GM) and with capture of $\mathrm{CO}_{2}$ in the biogas (GM+), and of green methane with the utilization of the carbon dioxide in the biogas along with green hydrogen to produce more green methane $(\mathrm{GM}+\mathrm{H})$ is given in Table 3. The cost of production of green methane augmented with carbon dioxide and hydrogen has been calculated by (a) calculating the cost of hydrogen used $(5.90 \mathrm{~g})$ at a price of USD $0.0336 / \mathrm{MJ}$ of hydrogen $(5.90 \mathrm{~g} \times 0.143 \mathrm{MJ} / \mathrm{g} \times \mathrm{USD} 0.0336 / \mathrm{MJ})$, (b) dividing that figure by 1.655 , because $1.655 \mathrm{MJ}$ are ultimately produced, and (c) adding it to the cost figure of straight green methane. The distribution cost of hydrogen via pipeline is estimated to be three times that of bio-methane due the higher pressure required to deliver it because of its lower density compared to methane [41]. The city gate price of grey methane (natural gas), which includes production, upgrading and transmission, is also given as the baseline fuel. Obviously, there is no difference in the cost of the production of green methane whether there is capture of the carbon dioxide in the biogas or not. In addition, the delivery price of green methane from energy crops is about $50 \%$ higher than that from organic wastes. Lastly the total cost of green hydrogen is one to three times higher than that of green methane. We may also note that the cost of production of blue hydrogen is comparable to the cost of production of green methane from energy crops. 


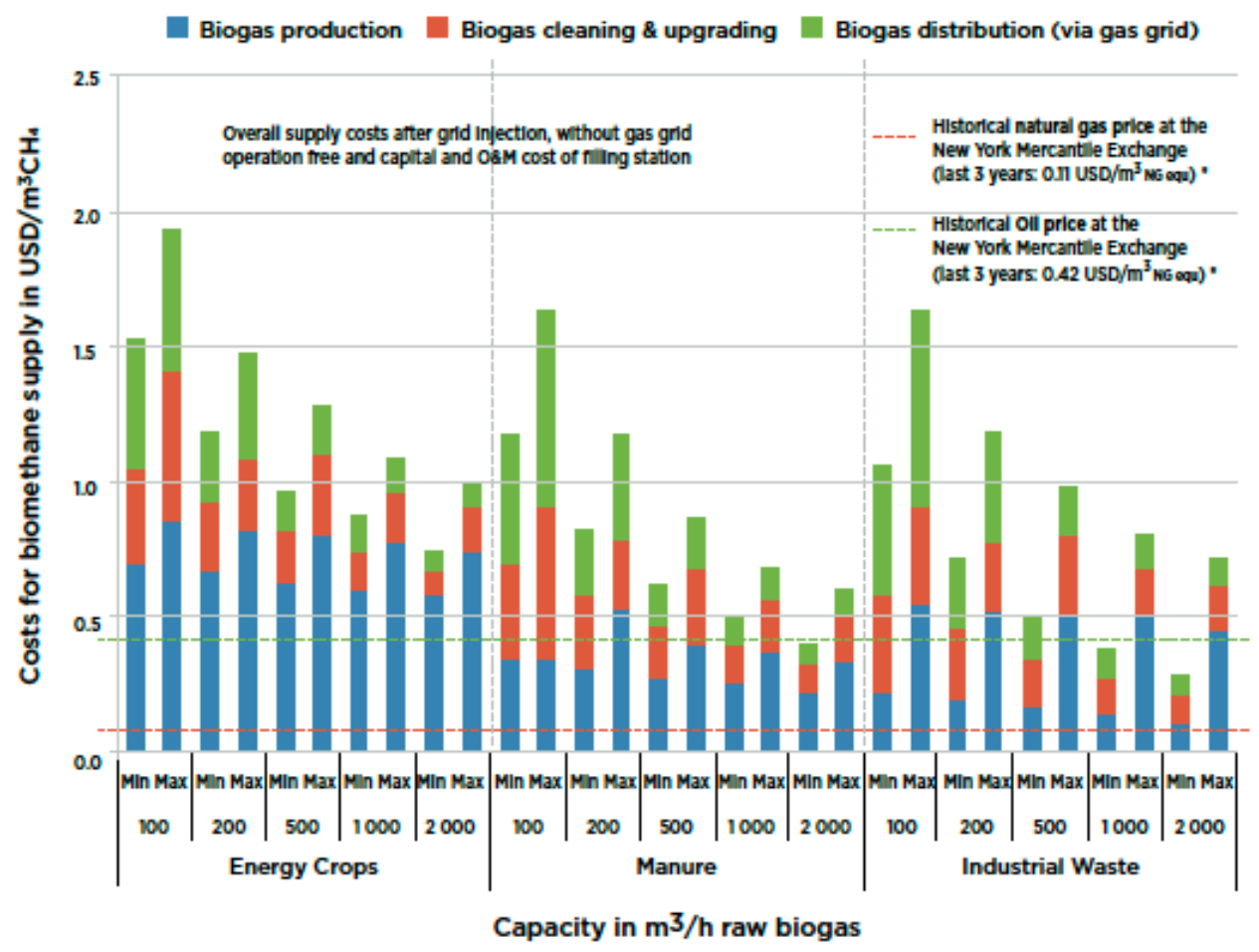

Figure 2. Biomethane cost of production, upgrading and distribution as function of production capacity and feedstock type (source: IRENA 2018 [28]).

Table 3. Cost comparison of green hydrogen from wind power, of green methane (biomethane) with or without $\mathrm{CO}_{2}$ capture, of green methane augmented with and without $\mathrm{CO}_{2}$ capture in the biogas and of grey methane (fossil) as the baseline.

\begin{tabular}{|c|c|c|c|c|}
\hline Cost Component & & Green $\mathrm{CH}_{4}$ & Green $\mathrm{CH}_{4}$ & \\
\hline USD/MJ & Green $\mathrm{H}_{2}$ & $\begin{array}{l}\text { Without } \mathrm{CO}_{2} \\
\text { Capture or with } \\
\mathrm{CO}_{2} \text { Capture }\end{array}$ & $\begin{array}{l}\text { With } \mathrm{CO}_{2} \text { Use } \\
\text { and Green } \mathrm{H}_{2}\end{array}$ & Grey $\mathrm{CH}_{4}$ \\
\hline Production & 0.0336 & $0.0085-0.0170$ * & $0.0256-0.0341$ * & \\
\hline Upgrading & 0.0000 & 0.0035 & 0.0035 & \\
\hline Distribution & 0.0083 & 0.0028 & 0.0028 & \\
\hline Total & 0.0419 & $0.0150-0.0233$ & $0.0319-0.0404$ & 0.0032 \\
\hline
\end{tabular}

${ }^{*}$ The cost range reflects production from organic wastes vs. that from energy crops.

\section{Pathway for the Adoption of Green Hydrogen}

The preceding cost analysis suggests that in the next decade and perhaps through 2050 a smart strategy must be adopted in order to establish the large-scale introduction of green hydrogen into the economy permanently this time around. A key component of this strategy is to determine the most important end uses of green hydrogen to facilitate its entry in the economy [42]. Important end uses are those that make the most sense in terms of cost effectiveness as well as the reduction in greenhouse gas emissions. End uses of green hydrogen may include: (a) replacing grey hydrogen in refining, ammonia, methanol and steel production; (b) water and space heating as well as industrial applications; (c) transportation; and (d) wind and solar power storage. Replacing grey hydrogen with green hydrogen in industrial applications is unlikely to occur any time soon and definitely cannot lead the transition because of cost. At the moment and in the foreseeable future, i.e., by 2050, blue hydrogen at best can replace grey hydrogen. However, new technologies in manufacturing, such as steel production from direct reduction using electricity, 
could eliminate the need of hydrogen altogether. In terms of water and space heating, the replacement of natural gas (grey methane) with green hydrogen makes no sense because of not only cost, but also technological developments and efficiency issues. The replacement of water heaters and furnaces with heat pumps driven by wind and solar electricity can be at least four times as efficient given that the best water heater, boiler or furnace can be 96-98\% efficient, but a heat pump driven by electricity from wind or solar can be 350-400\% efficient and also provide air-conditioning. Moreover, heat pumps are under development that can deliver process heat to industrial applications at high temperatures such as pulp, paper, food processing, and preheating for even higher temperature processes such as cement, glass and chemical manufacturing. A recent study suggests that electricity can supply $78 \%$ of process heat in industry using currently available technologies and up to 99\% with technologies under development [43]. Hydrogen can be an excellent energy storage medium for renewable but intermittent wind and solar power as these sources increase in penetration to replace fossil fuel generated power. However, it will take at least a decade and probably longer before wind and solar account for 30 to $40 \%$ penetration, at which point there would be a need for longer term storage. Batteries can be good for a few days, but for longer storage periods, the grid would need a fuel such as green methane and/or green hydrogen [44]. Transportation is the end use where green hydrogen can make an early entry in the market for a number of reasons to be discussed shortly. The thrust for the use of hydrogen in transportation has been based on fuel cell technology. Fuel cells were promoted twenty years ago and are promoted today once more by the Hydrogen Council, which was formed in 2017 and represents a fast-growing association of oil and gas companies [14,42,45]. Fuel cell technology has advanced substantially over the past several decades [40]. However, the use of fuel cells in transportation applications has yet to materialize. Of the various technologies, the polymer electrolyte membrane (PEM) fuel cells are considered to be the ones appropriate in transportation applications because of suitable operating temperature $\left(80^{\circ} \mathrm{C}\right.$ ) and power density (up to $1200 \mathrm{~mW} / \mathrm{cm}^{2}$ ) and total power output (up to $500 \mathrm{~kW}$ ). However, the required amount of platinum makes them quite expensive. Moreover, the system efficiency of a PEM fuel cell is in the 30-50\% range [46]. Taking also into account the energy required to transport, compress or liquefy hydrogen and store it on board a vehicle, the overall efficiency of a PEM-fuel-cell-powered small passenger vehicle could be about $0.5 \mathrm{kWh} / \mathrm{km}$. By comparison a similar size battery electric vehicle has a fuel consumption of $0.25 \mathrm{kWh} / \mathrm{km}$, including the losses of charging/discharging the battery and transmission of electricity [42]. That is to say, hydrogen fuel cell vehicles are half as efficient as battery electric vehicles. On the other hand, carbon dioxide emissions from power generation are relatively high at the present time, thereby making battery electric vehicles also high emitters of carbon dioxide despite their high efficiency. The carbon dioxide emissions from power generation, using those in the USA as an example, are summarized in Table 4 [47], and while there has been a reduction in carbon dioxide emissions by $24 \%$ from 2005 to 2019 , the current rate of $0.646 \mathrm{~kg} / \mathrm{kWh}$ or $179 \mathrm{~g} / \mathrm{MJ}$ is still high compared to those of green hydrogen and of green methane.

Table 4. Carbon dioxide emissions in the power generation sector of the USA.

\begin{tabular}{llllll}
\hline \multirow{2}{*}{ Year } & \multicolumn{3}{l}{ Source Mix in Power Generation \% } & Carbon Dioxide \\
\cline { 2 - 6 } & Coal & Natural Gas & Oil & Non-Fossil Source * & kg/kWh \\
\hline 2005 & 49.6 & 19.8 & 3.0 & 27.6 & 0.851 \\
\hline 2019 & 23.3 & 38.1 & 0.4 & 38.2 & 0.646 \\
\hline
\end{tabular}

* Non-fossil sources comprise $52 \%$ nuclear, $26 \%$ wind and solar, $17 \%$ hydro and $5 \%$ biomass.

A recent study has compared the life cycle carbon dioxide emissions per kilometer of three types of passenger vehicles as follows: (a) a conventional gasoline vehicle (CGV) representing the average European car; (b) the most efficient hybrid electric vehicle (HEV), a Toyota Prius Eco; and (c) the battery electric vehicle (BEV) Tesla Model 3, having an 
energy use of $15.6 \mathrm{kWh} / 100 \mathrm{~km}$, with average electricity emissions from a number of European countries and the USA $[48,49]$. The results of this study are shown in Figure 3.

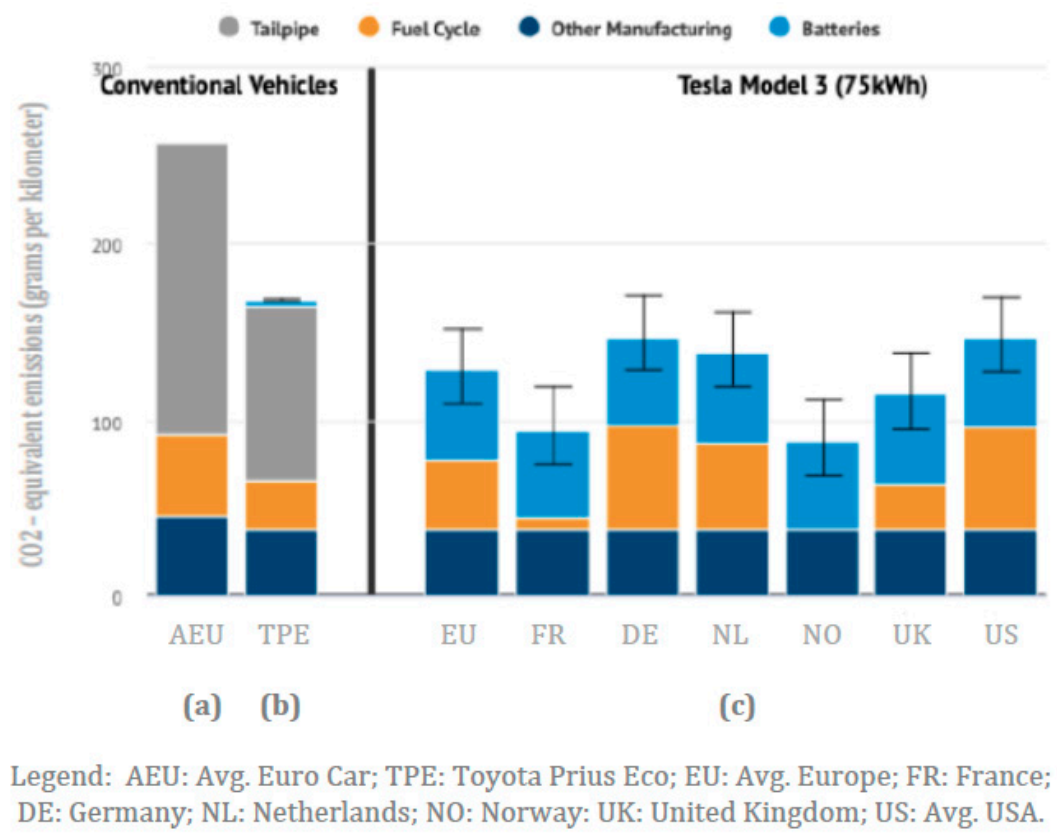

Figure 3. Comparison of the calculated life cycle emissions over 150,000 km of (a) a conventional gasoline vehicle (average European car), (b) the most efficient on the road hybrid electric vehicle (the Toyota Prius Eco) and (c) the Tesla Model 3 with $75 \mathrm{kWh}$ battery storage powered with the respective average electricity from a number of European counties and the USA-error bars indicate the uncertainty of the emissions of BEV batteries (reproduced from Carbon Brief [48] and an ICCT study [49]).

The calculated life cycle emissions of carbon dioxide show a number of important patterns that may be summarized as follows: (a) the manufacturing emissions of all these types of vehicles, excluding batteries for the BEVs, are comparable at about $50 \mathrm{~g} \mathrm{CO}_{2} / \mathrm{km}$; (b) the fuel cycle emissions for the gasoline vehicles that comprise oil production, transport, refining and distribution range from a low of $25 \mathrm{~g} \mathrm{CO}_{2} / \mathrm{km}$ for the $\mathrm{HEV}$ to a high of $50 \mathrm{~g} \mathrm{CO}_{2} / \mathrm{km}$ for the $\mathrm{CGV}$, i.e., they depend on the vehicle fuel efficiency; (c) the fuel cycle emissions for the electric vehicles, comprised of electricity generation and transmission, varies from a low of less than $5 \mathrm{~g} \mathrm{CO}_{2} / \mathrm{km}$ for countries with high penetration of nuclear power (France) and renewable power (Norway) to a high of $90 \mathrm{~g} \mathrm{CO} / \mathrm{km}$ for countries with still significant coal generation (Germany and the USA); (d) the battery manufacturing for BEVs is on the order of $50 \mathrm{~g} \mathrm{CO}_{2} / \mathrm{km}$, while that for $\mathrm{HEVs}$ is around $5 \mathrm{~g} \mathrm{CO} / \mathrm{km}$, because of the onboard size of batteries; and (e) the tailpipe emissions are on the order of $100 \mathrm{~g} \mathrm{CO}_{2} / \mathrm{km}$ for the HEVs and over $160 \mathrm{~g} \mathrm{CO}_{2} / \mathrm{km}$ for the CGVs. Obviously, these life cycle carbon dioxide emission figures depend on assumptions made by the modelling entities and can vary to a certain degree, occasionally showing electric vehicles emitting more carbon dioxide than conventional vehicles [48]. We may also note that the average life cycle greenhouse gas emissions for electric vehicle batteries (lithium-ion) are presently about $100 \mathrm{~kg}$ of carbon dioxide per kilowatt-hour [48]. This translates to $50 \mathrm{~g} / \mathrm{km}$ for the Tesla Model 3 BEV. Even if all the power required for the manufacturing of electric vehicle batteries were to have zero carbon dioxide emissions, there still would be a minimum of $31 \mathrm{~g} \mathrm{CO}_{2} / \mathrm{km}$ just from the batteries alone.

The consensus appears to be that when all electricity is derived from renewable sources, then the electric vehicles could provide the lowest possible carbon dioxide emissions. Furthermore, the inherent inefficiency of the drivetrain of a fuel cell electric vehicle (FCEV) vs. a BEV as well as the high cost suggests that FCEVs will never be able to compete with 
BEVs in terms of both carbon dioxide emissions and cost. We may also note that FCEVs are typically twice as efficient as CGVs and consequently roughly as efficient as HEVs [50]. Thus, the use of green hydrogen in transportation will not come about because of the largescale introduction of FCEVs. This is contrary to what, for example, the Hydrogen Council, is advocating [42]. Furthermore, wind and solar power are penetrating the market at a slow, but justifiable pace for a number of reasons: (a) existing power plants that cannot be closed down overnight because they represent a significant investment; (b) inadequate grid that needs upgrading to better accommodate distributed renewable sources; (c) relatively inexpensive and abundant natural gas (grey methane); and (d) higher capital cost of wind and solar power vs. natural gas power. In fact, fossil natural gas, being by far the cleanest fossil fuel with $\mathrm{CO}_{2}$ emissions per energy output, roughly half those from coal and about two-third those from oil, will accommodate the transition from fossil energy to renewable energy in the next several decades at the local as well at the global levels. That is to say, the impact of BEVs on climate change will remain marginal until power generation is fully decarbonized in industrialized countries initially and around the globe later on. This realization presents an opportunity for the introduction of green hydrogen into the economy as a fuel for vehicles. The details of this opportunity will be considered next.

\section{The Concept of the RHYME Fuel}

The competing technologies in road transportation consist of: (a) conventional vehicle (CV) with internal combustion engine (ICE) and a hydrocarbon fuel, typically gasoline, diesel or natural gas, representing the majority of vehicles on the road today; (b) hybrid electric vehicle (HEV) combining an ICE fueled by a hydrocarbon fuel with an electric motor and batteries charged by the ICE; (c) plug-in hybrid electric vehicle (PHEV), which is similar to the HEV with the added feature that batteries can be charged externally (grid); (d) battery electric vehicle (BEV) with only an electric motor and batteries charged externally (grid); and (e) fuel cell electric vehicles (FCEV) with an electric motor powered by a fuel cell utilizing onboard stored hydrogen fuel. The characteristics of these technologies are summarized qualitatively in Table 5 . A number of important conclusions can be drawn. First, the BEVs and the PHEVs in the electric mode have the lowest energy use, while CVs have roughly four times higher energy use with HEVs and FCEVs being in the middle. The life cycle carbon dioxide emissions are not reduced proportionally to the energy use of the particular type, although HEVs, PHEVs and BEVs have $40 \%$ lower emissions compared to the CVs and FCEVs under the prevailing current energy production schemes in industrialized countries. Third, the FCEVs show at the present time no environmental benefit and a high cost. Fourth, the two technologies that stand out are the PHEVs and the BEVs. Fifth, the PHEVs represent the better environmental choice in light of the fact that most daily trips are less than $50 \mathrm{~km}$, which means that these vehicles will be operated in the electric mode most of the time. For example, in the USA in 2017 the average daily distanced traveled was about $41.5 \mathrm{~km}$ and was comprised of an average of 2.7 trips of $15.4 \mathrm{~km}$ each [51].

The PHEV technology has the potential to facilitate the introduction of green hydrogen fuel in lieu of gasoline in the transportation sector, particularly for light-duty vehicles. We will demonstrate this potential by comparing two well-known production vehicles: (a) the PHEV Toyota Prius Prime; and (b) the BEV Tesla Model 3 with medium battery capacity as marketed in the USA for model year 2022. Relevant characteristics of these two vehicles are shown in Table 6 [52]. The annually driven distance is 15,000 km over a 10-year life of each vehicle and consists of $45 \%$ urban and $55 \%$ highway driving. 
Table 5. Summary of typical characteristics of competing technologies for road transportation as of 2021.

\begin{tabular}{lllllll}
\hline Technology & Energy Use & $\begin{array}{l}\text { Life Cycle } \mathbf{C O}_{\mathbf{2}} \\
\text { Emissions }\end{array}$ & Range & $\begin{array}{l}\text { Fueling } \\
\text { Time }\end{array}$ & Price & $\begin{array}{l}\text { Maturity } \\
\text { Quality }\end{array}$ \\
\cline { 2 - 7 } & $\mathbf{( k W h / k m )}$ & $\mathbf{( g / k m )}$ & $\mathbf{( k m )}$ & $\mathbf{( h )}$ & & \\
\hline CV & 0.60 & 250 & 700 & 0.15 & Low & High \\
\hline HEV & 0.30 & 150 & 1000 & 0.15 & Medium & Medium \\
\hline PHEV & $0.15-0.30$ & 150 & $50-1000$ & $5(2)-0.15$ & Medium & Medium \\
\hline BEV & 0.15 & 150 & 450 & $7(6)$ & Medium & Medium \\
\hline FCEV & 0.30 & 250 & 575 & 0.5 & High & Low
\end{tabular}

Notes: The assumed hydrocarbon fuel for CV, HEV and PHEV is gasoline and brown hydrogen for FCEV. The range for PHEV indicates pure electric mode and pure fuel mode. The lower (in parenthesis) fueling time for PHEV and BEV indicates a fast-charging mode for the batteries.

Table 6. Comparison of the key characteristics of a PHEV production vehicle (Toyota Prius Prime) and a BEV (Tesla Model 3) production vehicle in the USA.

\begin{tabular}{lll}
\hline Characteristic & Toyota Prius Prime & Tesla Model 3 \\
\hline Type & Mid-size sedan & Mid-size sedan \\
\hline Propulsion & Electric + gasoline & Electric \\
\hline Range Total & $1024 \mathrm{~km}$ & $480 \mathrm{~km}$ \\
\hline Battery Storage & $8.8 \mathrm{kWh}$ & $75 \mathrm{kWh}$ \\
\hline Fuel Tank & $43 \mathrm{~L}$ & $\mathrm{n} / \mathrm{a}$ \\
\hline Fuel Efficiency Electric & $0.156 \mathrm{kWh} / \mathrm{km}$ & $0.150 \mathrm{kWh} / \mathrm{km}$ \\
\hline Fuel Efficiency Gasoline & $0.39 \mathrm{kWh} / \mathrm{km}$ & $\mathrm{n} / \mathrm{a}$ \\
\hline $\mathrm{CO}_{2}$ Vehicle Emissions & $48.75 \mathrm{~g} / \mathrm{km}$ & $0 \mathrm{~g} / \mathrm{km}$ \\
\hline $\mathrm{CO}_{2}$ Fuel Cycle Emissions & $51.25 \mathrm{~g} / \mathrm{km}$ & $68.75 \mathrm{~g} / \mathrm{km}$ \\
\hline $\mathrm{CO}_{2}$ Manufacturing Emissions ${ }^{+}$ & $45 \mathrm{~g} / \mathrm{km}$ & $45 \mathrm{~g} / \mathrm{km}$ \\
\hline $\mathrm{CO}_{2}$ Li-ion Battery Emissions ${ }^{+}$ & $5.85 \mathrm{~g} / \mathrm{km}$ & $50 \mathrm{~g} / \mathrm{km}$ \\
\hline Total Life Cycle CO ${ }_{2}$ Emissions & $150.85 \mathrm{~g} / \mathrm{km}$ & $163.75 \mathrm{~g} / \mathrm{km}$ \\
\hline $\mathrm{MSRP}^{*}$ & $\mathrm{USD} 28,220-\mathrm{USD} 34,000$ & $\mathrm{USD} 44,990$ \\
\hline Annual Energy Cost & USD 700 & $\mathrm{USD} 450$
\end{tabular}

Notes: Information provided by US DOE and US EPA [52] except $\left(^{+}\right)$calculated on the basis of information in Figure 3 and in Section 4 and ${ }^{*}$ ) supplied by Toyota Motor Co. and by Edmunds https:/ /www.edmunds.com/ tesla/model-3 (accessed on 5 November 2021). One liter of gasoline has $8.9 \mathrm{kWh}$. The gasoline and electricity fuel cycle $\mathrm{CO}_{2}$ emissions are based on the present average values in the USA [52].

The results in Table 6 are quite instructive in three important aspects: (a) the life cycle carbon dioxide emissions of BEVs are about $10 \%$ higher than those of PHEVs at the present time; (b) the tailpipe emissions of the PHEV running on gasoline are similar, albeit slightly lower, than the lithium-ion battery emissions and (c) the price of BEVs is $30 \%$ to $50 \%$ higher than those of the PHEVs. Granted this conclusion is based on the careful examination of the two best models in their respective category, but a cursory examination of several models by other manufacturers shows similar results [52]. On the other hand, these two production models showcase what the respective technology can attain at the present time. We know that in the future, say, by 2050 when hopefully most of electricity is generated by renewable energy, the fuel cycle emissions of the BEVs may be reduced to as low as about $1.00 \mathrm{~g} / \mathrm{km}$ assuming wind power at $6 \mathrm{~g} / \mathrm{kWh}$ of carbon dioxide emissions and a $90 \%$ power transmission efficiency. Carbon dioxide emissions for manufacturing may be reduced by $30 \%$ with the use of green electricity to $31.5 \mathrm{~g} / \mathrm{km}$. Moreover, the lithium battery emissions for the BEVs may be as low as $31 \mathrm{~g} / \mathrm{km}$ (see Section 4), bringing the total carbon dioxide life cycle emissions of the Tesla Model 3 to about $63.5 \mathrm{~g} / \mathrm{km}$. Studies have 
shown that $73 \%$ of trips on PHEVs with $56 \mathrm{~km}$ (35 mi) electric range are performed on the electric mode [53]. The electric portion of the fuel life cycle carbon dioxide emission of the PHEVs will be reduced accordingly from $37.41 \mathrm{~g} / \mathrm{km}$ presently $(73 \%$ driving on electric power and $27 \%$ driving on gasoline) to $4.38 \mathrm{~g} / \mathrm{km}$, while the gasoline portion will remain unchanged at $51.25 \mathrm{~g} / \mathrm{km}-37.41 \mathrm{~g} / \mathrm{km}=13.84 \mathrm{~g} / \mathrm{km}$. Moreover, the lithium-ion battery life cycle $\mathrm{CO}_{2}$ emissions of the PHEV will also be reduced by $40 \%(20 / 50)$ to $2.34 \mathrm{~g} / \mathrm{km}$. Thus, the total carbon dioxide life cycle emission of the Toyota Prius Prime would be: $48.75 \mathrm{~g} / \mathrm{km}+4.38 \mathrm{~g} / \mathrm{km}+13.84 \mathrm{~g} / \mathrm{km}+45.00 \mathrm{~g} / \mathrm{km}+2.34 \mathrm{~g} / \mathrm{km}=114.31 \mathrm{~g} / \mathrm{km}$. Of the carbon dioxide life cycle emissions for the PHEVs, $48.75 \mathrm{~g} / \mathrm{km}+13.84 \mathrm{~g} / \mathrm{km}=62.59 \mathrm{~g} / \mathrm{km}$ or $54.7 \%$ of the total would be the result of using gasoline. If we were to employ a different fuel such as green hydrogen $(\mathrm{GH})$, the carbon dioxide emissions of the PHEVs would fall well below those of the BEVs in the future. Moreover, if we were to employ green methane with carbon dioxide capture $(\mathrm{GM}+)$ or green methane augmented with the conversion of carbon dioxide in the biogas with green hydrogen $(\mathrm{GE}+\mathrm{GM}+\mathrm{H})$, the total carbon dioxide emission of PHEVs would become even lower, the existence of tailpipe emissions notwithstanding. The BEVs have no such option available to them. The life cycle carbon dioxide emissions of BEVs operating on wind power and of the PHEV employing wind power along with either GH, or GM+ or GM+H are summarized in Table 7. The fuel cycle carbon dioxide emissions are: for green hydrogen $12.708 \mathrm{~g} / \mathrm{kWh}$ (3.53 g /MJ per Table 1); for green methane with $\mathrm{CO}_{2}$ capture $-136.69 \mathrm{~g} / \mathrm{kWh}(-37.97 \mathrm{~g} / \mathrm{MJ}$ per Table 2); and for green methane augmented with capture of $\mathrm{CO}_{2}$ and conversion with green hydrogen to additional green methane $-77.16 \mathrm{~g} / \mathrm{kWh}(-35.47 \mathrm{~g} / 1.655 \mathrm{MJ}$ per Table 2$)$. The energy use by a PHEV is divided in the proportion $73-27 \%$ between the electric mode and the fuel mode, respectively. Thus, the carbon dioxide fuel cycle (FC) emissions of the PHEV on the electric mode for either fuel would be:

$\mathrm{CO}_{2}$ PHEV FC emission in electric mode:

$6 \mathrm{~g} / \mathrm{kWh} \times 0.156 \mathrm{kWh} / \mathrm{km} \times 0.73=0.68 \mathrm{~g} / \mathrm{km}$

$\mathrm{CO}_{2}$ PHEV FC emission in GH mode:

$12.708 \mathrm{~g} / \mathrm{kWh} \times 0.39 \mathrm{kWh} / \mathrm{km} \times 0.27=1.34 \mathrm{~g} / \mathrm{km}$

$\mathrm{CO}_{2}$ PHEV FC emission in GM+ mode:

$-136.69 / \mathrm{kWh} \times 0.39 \mathrm{kWh} / \mathrm{km} \times 0.27=-14.39 \mathrm{~g} / \mathrm{km}$

Table 7. Comparison of the life cycle carbon dioxide emissions of the best current technology for PHEVs and for BEVs under the assumption of wind electricity (WE) as well as green hydrogen $(\mathrm{WE}+\mathrm{GH})$, green methane with carbon dioxide capture $(\mathrm{WE}+\mathrm{GM}+)$ and green methane augmented with the conversion of the carbon dioxide and green hydrogen $(W E+G M+H)$.

\begin{tabular}{lcccc}
\hline Characteristic & \multicolumn{2}{c}{ BEV } & \multicolumn{3}{c}{ PHEV } \\
\hline Type & Mid-Size Sedan & \multicolumn{3}{c}{ Mid-Size Sedan } \\
\hline Energy Source & $\mathrm{WE}$ & $\mathrm{WE}+\mathrm{GH}$ & $\mathrm{WE}+\mathrm{GM}+$ & $\mathrm{WE}+\mathrm{GM}+\mathrm{H}$ \\
\hline Battery Storage, $\mathrm{kWh}$ & 75 & 8.8 & 8.8 & 8.8 \\
\hline Fuel Storage, $\mathrm{kWh}$ & $\mathrm{n} / \mathrm{a}$ & 382.7 & 382.7 & 382.7 \\
\hline Electric Efficiency, $\mathrm{kWh} / \mathrm{km}$ & 0.150 & 0.15 & 0.156 & 0.156 \\
\hline Fuel Efficiency, $\mathrm{kWh} / \mathrm{km}$ & $\mathrm{n} / \mathrm{a}$ & 0.39 & 0.39 & 0.39 \\
\hline Range, km & 480 & 1024 & 1024 & 1024 \\
\hline $\mathrm{CO}_{2}$ Vehicle Emissions, g/km & 0 & 0 & 18.74 & 18.74 \\
\hline $\mathrm{CO}_{2}$ Fuel Cycle Emissions, $\mathrm{g} / \mathrm{km}$ & 1.00 & 2.02 & -14.39 & -8.12 \\
\hline $\mathrm{CO}_{2}$ Manufacturing Emissions, g/km & 31.50 & 31.50 & 31.50 & 31.50 \\
\hline $\mathrm{CO}_{2}$ Li-ion Battery Emissions, g/km & 31.00 & 3.51 & 3.51 & 3.51 \\
\hline Total Life Cycle $\mathrm{CO}_{2}$ Emissions, $\mathrm{g} / \mathrm{km}$ & 63.50 & 37.03 & 39.36 & 45.63 \\
\hline
\end{tabular}


The carbon dioxide tailpipe (TP) emissions for the green methane are calculated to be:

$$
\begin{gathered}
\mathrm{CO}_{2} \text { PHEV TP emission in GM+ mode: } \\
178 \mathrm{~g} / \mathrm{kWh} \times 0.39 \mathrm{kWh} / \mathrm{km} \times 0.27=18.74 \mathrm{~g} / \mathrm{km}
\end{gathered}
$$

The results in Table 7 indicate that on a life cycle basis, BEVs powered by wind energy emit $50 \%$ more carbon dioxide than PHEVs powered by wind energy and fueled by either green hydrogen or green methane with carbon dioxide capture.

The scale of implementation of wind power required to electrify an advanced industrial economy such as that of the USA or of the EU, so that BEVs can approach the lower carbon dioxide emissions as shown in Table 7, would be quite massive in the next 30 years. However, even if this massive renewable energy electrification were to happen, the results of the preceding analysis indicate that BEVs would not offer the best solution in terms of reducing the life cycle carbon dioxide emissions in transportation. The better choice would be PHEVs employing either green hydrogen or green methane or a combination of both of these green fuels. This avoids the need for large battery storage on board the vehicle and is consistent with the fact that almost three-quarters of daily travel is under $50 \mathrm{~km}$. In addition to having significantly lower life cycle carbon dioxide emissions, a PHEV also has a significantly lower cost, which is dictated by the size of the onboard lithium-ion batteries. A PHEV will operate roughly three-quarters of the distance traveled annually on electricity and the remainder on the green fuel. The green fuel of choice should be a combination of green or renewable hydrogen and of green methane choice to reduce the life cycle emission of carbon dioxide and compete economically with fossils fuels and their cleaner derivatives, as we examine in the following section. Thus, the introduction of PHEVs operating on such a green fuel will also ensure and facilitate the introduction of hydrogen into the economy. We call this green fuel conceptually "Renewable HYdrogen and MEthane" or RHYME for short. We discuss the characteristics of the RHYME fuel in transportation in the next section.

\section{The RHYME Fuel Characteristics}

The proposed RHYME fuel represents a concept with a flexible green fuels composition in order to take advantage in transportation of the resulting significant reduction of life cycle carbon dioxide emissions vis-à-vis an electricity-only mode in a cost-effective approach that can begin its realization right away. Because green hydrogen is a component of the RHYME fuel, the utilization of green hydrogen can begin becoming part of the energy system of an industrial economy right away as well. There are two elements already in place to facilitate the introduction of the RHYME fuel: (a) all major automotive manufacturers include in their line of production PHEVs [52]; and (b) biomethane is already part of the alternative transportation fuels market and is gradually increasing its contribution both in the USA and the EU $[28,36-38,54,55]$. For example, in the USA in 2020 some 1.45 billion gasolineequivalent liters of renewable natural gas (RNG) was used and RNG accounted for $53 \%$ of the natural gas used in transportation in the country. Moreover, the use of RNG in the USA has almost quadrupled since 2016. The missing element is the production of green hydrogen that can be used along with green methane or biomethane as the alternative fuel to gasoline in PHEVs. At the present time, there is a limited number of FCEVs that are fueled by hydrogen. We believe that this is the not the best path toward the commercialization of green hydrogen for at least two major reasons: (a) FCEVs are not the best choice compared to BEVs and PHEVs due to higher vehicle cost and lower efficiencies; and (b) the price of green hydrogen is too high, thereby making the ownership of an FCEV even costlier. A mixture of green hydrogen and green methane can be readily accommodated in ICEs employed by PHEVs. In fact, a mixture of up to $20 \%$ hydrogen and at least $80 \%$ (fossil) methane by volume has been promoted for use in ICEs as far back as the late 1980s under the trade name "Hythane" [56]. It appears that the optimal mix of hydrogen and methane in an ICE is in the range of $15 \%$ to $20 \%$ by volume, the lower percentage being applicable to heavy duty vehicle engines and the higher to light duty vehicle engines $[57,58]$. The mixture of hydrogen and methane (both in their gaseous forms) improves the combustion of methane 
by expanding the narrow flammability range, increasing the burning speed and lowering the ignition temperature of pure methane, thereby improving fuel efficiency $[59,60]$. The hydrogen and methane mixture reduces also the emissions of nitrous oxide by as much as a factor of two from the already lower such emissions of a natural-gas-fueled vehicle by allowing an even leaner air-fuel mixture that is supported by the high flammability of hydrogen $[58,60]$. It should be also noted that the high-octane number of methane and the even higher one for hydrogen support the use of high compression-spark-ignited ICEs approaching that of compression-ignited ICEs for increased fuel efficiency. The tail pipe carbon dioxide emissions of the mixture of green hydrogen and green methane will be modified in proportion to the mass percentage composition of the respective emissions of the two components. The concept of the RHYME fuel is different from the trademark Hythane fuel in two significant aspects: (a) it is composed by definition of $100 \%$ green fuels, respectively, hydrogen and methane; and (b) the hydrogen-methane volumetric ratio can vary to accommodate a particular type of ICE with a likely range of 15-85 to 20-80 percent. The RHYME fuel being gaseous would have to be compressed to the standard $250 \mathrm{bar}$ pressure that compressed natural gas vehicles employ. Depending on the hydrogen $(X \%)$ to methane ratio (Y\%), we can designate the RHYME fuel as RHYME X-Y. Thus RHYME 100-0 would be pure green hydrogen and RHYME 0-100 would be pure green methane. Some of the relevant-to-transportation characteristics of the RHYME fuel for the likely range of $X$ and $Y$ values are summarized in Table 8. The use of the RHYME fuel may also increase the fuel efficiency of an ICE engine by a conservative 5\%, resulting in an energy consumption of $0.37 \mathrm{kWh} / \mathrm{km}$ for mid-side passenger vehicles and a reduction of the corresponding carbon dioxide life cycle emissions of green methane to $38.42 \mathrm{~g} / \mathrm{km}$ and $44.69 \mathrm{~g} / \mathrm{km}$ for the two different options of green methane per Table 7.

Table 8. Characteristics of the RHYME 15-85 and RHYME 20-80 fuel relevant to transportation.

\begin{tabular}{lll}
\hline Property & RHYME 15-85 & RHYME 20-80 \\
\hline Volumetric $\mathrm{H}_{2}-\mathrm{CH}_{4}$ Composition, \% & $15-85$ & $\mathbf{2 0 - 8 0}$ \\
\hline Mass $\mathrm{H}_{2}-\mathrm{CH}_{4}$ Composition, \% & $0.022-0.978$ & $0.031-0.969$ \\
\hline Energy Content at 250 bar, $\mathrm{kWh} / \mathrm{L}$ & 1.66 & 1.60 \\
\hline Octane Number, $\#$ & 109 & 110 \\
\hline Fuel Efficiency Mid-Size Vehicle, $\mathrm{kWh} / \mathrm{km}$ & 0.37 & 0.37 \\
\hline Life Cycle $\mathrm{CO}_{2}$ Emissions, $\mathrm{g} / \mathrm{km}$ & 38.39 or 44.52 & 38.37 or 44.45 \\
\hline $\begin{array}{l}\text { Note: the two figures for the life cycle } \mathrm{CO}_{2} \text { emissions represent the two different sources of green methane } \\
\text { (WE + GM+) and (WE + GM + } \mathrm{H} \text { ) per Table 7. }\end{array}$
\end{tabular}

The use of natural gas as a cleaner source of fossil energy compared to coal and to oil has been increasing steadily in the past 40 years. It has been projected that by 2030, natural gas would constitute the largest primary energy source globally [61]. Since the beginning of the 21st century, the application of new techniques for the extraction of natural gas have accelerated its production and use [62]. The production of natural gas in the USA, for example, has increased from $531 \times 10^{9} \mathrm{~m}^{3}$ in 2000 to $932 \times 10^{9} \mathrm{~m}^{3}$ in 2021 [63]. Thus, in a twenty-year period, the production of natural gas in the USA has almost doubled and natural gas has become the largest primary energy source in the country, allowing among others, the reduction by a factor of two in the use of coal for power generation. The USA has also a large and well-integrated natural gas pipeline system comprised of about 3.2 million kilometers of distribution and almost 0.6 million kilometers of collection and transmission pipelines. The production of green methane in the USA as a transportation fuel began less than ten years ago and is now increasing at an annual rate of about 25 percent [55]. The near future potential for the production of the green methane in the US has been estimated at about $800 \mathrm{PJ}$ per year or roughly $25 \times 10^{9} \mathrm{~m}^{3}$ per year [28]. We believe that the long-term potential for the production of green methane in the USA is at least an order of magnitude larger and perhaps as high 25 times higher at about $650 \times 10^{9} \mathrm{~m}^{3}$ per annum $[27,33]$. Other 
countries with large near future green methane production potential include China, India, Germany and Brazil, but only Germany has an extensive natural gas distribution system similar to that in the USA [28]. Consequently, the majority of biogas production globally is employed to supply heat and electricity instead of being upgraded into green methane and injected into the pipeline grid. However, a shift is underway, at least among industrialized countries, to upgrade biogas into green methane and inject it into the respective national natural gas pipeline grid where it can be used for any suitable use, including transportation. The driving force of this shift is derived from climate change concerns and the advancement of "net zero carbon" policies, which promote through a variety of financial incentives the use of low carbon fuels.

\section{The Implementation of the RHYME Fuel}

The implementation of the concept of the RHYME fuel in the short term, i.e., in the next ten years or so, represents a practical means to introduce green hydrogen into the energy sector on a permanent basis. An implementation scenario is considered using as an example the current situation with green methane in the USA. As we already mentioned, the use of RNG in the United States stands at about 1.45 billion gasoline-equivalent liters as of 2020 and has shown an average increase rate of about $28 \%$ per annum in the past five years. This amount of green methane, which does not include any carbon dioxide capture and reuse at the moment, is equal to about $1.3 \times 10^{9} \mathrm{Nm}^{3}$ of methane and represents roughly $5 \%$ of the country's short-term biomethane potential and a little over $0.1 \%$ of the current production of natural gas. If the average annual increase rate of $28 \%$ can be maintained in this decade, then it will take about 12 years for the produced green methane to reach an annual production rate of just over $25 \times 10^{9} \mathrm{Nm}^{3}$, i.e., reach the short-term potential of the country. The capture of the carbon dioxide in the generated biogas and its use along with green hydrogen will generate an additional $25.2 \times 10^{9} \mathrm{Nm}^{3} \times 0.655=16.5 \times 10^{9} \mathrm{Nm}^{3}$ of green methane (see Table 2). The amount of hydrogen required for the production of one billion normal cubic meters of green methane $(717,200,000 \mathrm{~kg}$ at an STP density of $0.7172 \mathrm{~kg} / \mathrm{m}^{3}$ ) is equal to $358,600,000 \mathrm{~kg}$ or $3.989 \times 10^{9} \mathrm{Nm}^{3}$ of hydrogen (STP density of $0.0899 \mathrm{~kg} / \mathrm{m}^{3}$ ) based on Equation (11) whereby $8 \mathrm{~kg}$ of hydrogen are required to generate $16 \mathrm{~kg}$ of methane. The required wind electricity to produce via electrolysis this amount of hydrogen is going to be: $3.989 \times 10^{9} \mathrm{~m}^{3} \times 4.1 \mathrm{kWh} / \mathrm{m}^{3}=16.355 \times 10^{9} \mathrm{kWh}$. The required wind power would be $6.2 \mathrm{GW}$ at an average $30 \%$ capacity factor. The required electrolysis capacity is calculated on the basis of a production rate of $55 \times 10^{6} \mathrm{Nm}^{3}$ of hydrogen per year by a $100 \mathrm{MW}$ unit. There will be additional need for hydrogen production in order to generate the RHYME fuel. For example, the RHYME 20-80 fuel would require $0.2 \times 10^{9} \mathrm{Nm}^{3}$ of green hydrogen for every $0.8 \times 10^{9} \mathrm{Nm}^{3}$ of green methane. The results of this analysis with the aforementioned assumptions are summarized in Table 9.

We have also calculated the required capital cost for implementing the short-term introduction of the RHYME 20-80 fuel in the next 12 years. The capital cost for green methane production is estimated to be USD $0.1 / \mathrm{Nm}^{3}$ of methane produced [28]. The capital cost of electrolysis is expected to be around USD $540 / \mathrm{kW}$ and the cost of wind power could be as low as USD $1000 / \mathrm{kW}$ as we have already discussed (Section 2). The calculated capital cost is also included in Table 9. The required average total annual capital investment over the 12-year period amounts to about USD 66.5 billion. The wind power capital cost amounts to almost $86 \%$ of the total investment. While this amount of investment is well within the ability of the private sector to finance, it will require a concerted effort on the part of both the private and public sectors, the latter developing a coherent policy toward the objective. We may also note that additional wind power generation will be required to supply the electric portion of the energy required for the PHEVs. This electricity will represent the energy use for the average $73 \%$ of the annual driving distance with electric propulsion. 
Table 9. Short term introduction of green hydrogen in transportation through the implementation of the RHYME 20-80 fuel in the United States.

\begin{tabular}{llll}
\hline \multirow{2}{*}{ Parameter } & \multicolumn{3}{c}{ Year } \\
\cline { 2 - 4 } & $\mathbf{2 0 2 0}$ & $\mathbf{2 0 2 5}$ & $\mathbf{2 0 3 2}$ \\
\hline Green Methane Production, $\mathrm{m}^{3}$ & $1.3 \times 10^{9}$ & $4.5 \times 10^{9}$ & $25.2 \times 10^{9}$ \\
\hline Carbon Dioxide in Biogas Use, $\%^{\prime}$ & 0 & 100 & 100 \\
\hline Green Hydrogen required with $\mathrm{CO}_{2}, \mathrm{~m}^{3}$ & 0 & $18 \times 10^{9}$ & $100.5 \times 10^{9}$ \\
\hline Additional Green Methane Production, $\mathrm{m}^{3}$ & 0 & $3.0 \times 10^{9}$ & $16.5 \times 10^{9}$ \\
\hline Total Green Methane Production, $\mathrm{m}^{3}$ & $1.3 \times 10^{9}$ & $7.5 \times 10^{9}$ & $41.7 \times 10^{9}$ \\
\hline Green Hydrogen required for RHYME, $\mathrm{m}^{3}$ & 0 & $1.9 \times 10^{9}$ & $10.4 \times 10^{9}$ \\
\hline Total Green Hydrogen Production, $\mathrm{m}^{3}$ & 0 & $19.9 \times 10^{9}$ & $110.4 \times 10^{9}$ \\
\hline Total RHYME 20-80 Fuel Production, $\mathrm{m}^{3}$ & 0 & $9.4 \times 10^{9}$ & $52.1 \times 10^{9}$ \\
\hline Wind Power required for H ${ }_{2}$ Production, GW & 0 & 123 & 685 \\
\hline Electrolysis Capacity required, GW & 0 & 36 & 200 \\
\hline Green Methane Production Capital Cost, USD & $0.130 \times 10^{9}$ & $0.750 \times 10^{9}$ & $4.170 \times 10^{9}$ \\
\hline Wind Power Capital Cost, USD & 0 & $123 \times 10^{9}$ & $685 \times 10^{9}$ \\
\hline Hydrogen via Electrolysis & 0 & $19.4 \times 10^{9}$ & $108 \times 10^{9}$ \\
\hline Total Capital Cost, USD & $0.130 \times 10^{9}$ & $133.15 \times 10^{9}$ & $797.17 \times 10^{9}$ \\
\hline
\end{tabular}

It is instructive to also calculate the benefits of such an investment in the energy sector beyond the obvious environmental benefits in attaining "net zero carbon dioxide emissions". The average fuel efficiency of new gasoline fueled light-duty vehicles in the USA is $0.84 \mathrm{kWh} / \mathrm{km}(25 \mathrm{mpg})$. These vehicles comprise passenger cars, sport utility vehicles, small vans, small (pick-up) trucks and motorcycles and consumed 428 billion liters of gasoline in 2020 [64]. It should also be noted that $10 \%$ by volume of gasoline is renewable ethanol. Thus, the oil-derived portion of the gasoline usage was about 385 billion liters in 2020 and the bioethanol amounted to 43 billion liters. The use of PHEV technology across the board may increase the average fuel efficiency by a conservative $50 \%$, thereby bringing it to $0.56 \mathrm{kWh} / \mathrm{km}$ [58]. For example, the $2022 \mathrm{PHEV}$ sport utility vehicle models for sale in the USA range in fuel efficiency from a high of $0.20 \mathrm{kWh} / \mathrm{km}$ (electric) and $0.46 \mathrm{kWh} / \mathrm{km}$ (gasoline) to a low of $0.26 \mathrm{kWh} / \mathrm{km}$ (electric) and $0.60 \mathrm{kWh} / \mathrm{km}$ (gasoline). Thus, the implementation of PHEVs across all categories of vehicles could reduce gasoline consumption conservatively to:

Gasoline consumption of PHEVs:

$$
428 \times 10^{9} \mathrm{~L} / \mathrm{yr} \times(1 / 1.5) \times 0.27=77 \times 10^{9} \mathrm{~L} / \mathrm{yr}
$$

Given that $1 \mathrm{Nm}^{3}$ of the RHYME 20-80 fuel has nearly the same energy content as one liter (L) of gasoline with $10 \%$ ethanol content, we conclude that the equivalent amount of RHYME 20-80 fuel required to replace the annual gasoline consumption of PHEVs would be about $77 \times 10^{9} \mathrm{Nm}^{3}$ per year. About $68 \%$ of this demand can be met from the existing organic wastes per Table 8 . The remainder $22 \%$ or about $25 \times 10^{9} \mathrm{Nm}^{3}$ of RHYME 20-80 fuel can be met by increasing the production of green methane through the utilization of some of the corn used in bioethanol production to produce more green methane via anaerobic digestion, capture the carbon dioxide in the biogas and utilize it with green hydrogen to generate additional green methane. It is well established than one hectare of corn can produce on an energy content three times as much green methane as it does bioethanol, because the entire biomass of the corn plant is used for the production of methane vs. just the corn kernels used for bioethanol [28]. Moreover, $1 \mathrm{Nm}^{3}$ of green methane is equal to about $1.5 \mathrm{~L}$ of bioethanol in terms of energy content. Consequently, if 
the entire corn production for bioethanol was shifted to produce green methane instead, then we would obtain as many as $86 \times 10^{9} \mathrm{~m}^{3}$ of green methane annually. In the case of the implementation of the (WE $+\mathrm{GM}+\mathrm{H})$ fuel, there will be a need to produce an additional $12 \times 10^{9} \mathrm{Nm}^{3}$ of green methane from corn in order to generate ultimately $20 \times 10^{9} \mathrm{Nm}^{3}$ of green methane $\left(12 \times 10^{9} \mathrm{Nm}^{3} \times 1.655\right)$ and $25 \mathrm{Nm}^{3}$ of RHYME 20-80 fuel. Thus, it would be necessary to reduce bioethanol production by 6 billion liters and utilize $14 \%$ of the current production of corn to bioethanol to produce instead $12 \times 10^{9} \mathrm{Nm}^{3}$ of green methane. In addition, the remainder of the corn used for bioethanol can be shifted to produce $74 \times 10^{9} \mathrm{Nm}^{3}$ of green methane annually via anaerobic digestion. This green methane can be further augmented to $122 \times 10^{9} \mathrm{Nm}^{3}$ of green methane with the capture of carbon dioxide and green hydrogen to produce more $(\mathrm{WE}+\mathrm{GM}+\mathrm{H})$ fuel. The long-term development, i.e., by 2050 of the use of green hydrogen in transportation through the expansion of the use of the RHYME fuel is summarized in Table 10 as option A.

Table 10. Long term development of green hydrogen in transportation through the implementation of the RHYME fuels in the United States and PHEV/HEV technologies to replace gasoline and diesel fuels.

\begin{tabular}{|c|c|c|}
\hline \multirow{2}{*}{ Parameter } & \multicolumn{2}{|c|}{ Year } \\
\hline & 2032 & 2050 \\
\hline \multicolumn{3}{|l|}{ A. RHYME 20-80 Fuel in lieu of Gasoline } \\
\hline Green Methane Production $(\mathrm{WE}+\mathrm{GM}+\mathrm{H}), \mathrm{m}^{3} / \mathrm{yr}$ & $41.7 \times 10^{9}$ & $61.7 \times 10^{9}$ \\
\hline Carbon Dioxide in Biogas Capture and Reuse for $\mathrm{H}_{2}, \%$ & 100 & 100 \\
\hline \multicolumn{3}{|l|}{ Green Methane Sources } \\
\hline Organic Wastes, \% & 100 & 100 \\
\hline Energy Crops-Current Corn, \% & 0 & 14 \\
\hline Green Hydrogen Production, $\mathrm{m}^{3} / \mathrm{yr}$ & $110.4 \times 10^{9}$ & $163.7 \times 10^{9}$ \\
\hline Wind Power for Hydrogen Production, GW & 685 & 1016 \\
\hline Wind Power for Electric Propulsion, GW & 0 & 307 \\
\hline Total Wind Power for Light Duty PHEVs, GW & 685 & 1323 \\
\hline \multicolumn{3}{|l|}{ B. RHYME 20-80 Alternative in lieu of Gasoline } \\
\hline Green Methane Production (WE + GM+), $\mathrm{m}^{3} / \mathrm{yr}$ & $25.2 \times 10^{9}$ & $78.2 \times 10^{9}$ \\
\hline Carbon Dioxide in Biogas Capture and Reuse, \% & 100 & 100 \\
\hline \multicolumn{3}{|l|}{ Green Methane Sources } \\
\hline Organic Wastes & 100 & 100 \\
\hline Energy Crops-Current Corn, \% & 0 & 60 \\
\hline Green Hydrogen Production, $\mathrm{m}^{3} / \mathrm{yr}$ & $6.3 \times 10^{9}$ & $19.6 \times 10^{9}$ \\
\hline Wind Power for Hydrogen Production, GW & 39 & 121 \\
\hline Wind Power for Electric Propulsion, GW & 0 & 307 \\
\hline Total Wind Power for Light Duty PHEVs, GW & 39 & 448 \\
\hline \multicolumn{3}{|l|}{ C. RHYME 15-85 Fuel in lieu of Diesel Fuel in HDV } \\
\hline Green Methane Production (WE + GM+), $\mathrm{m}^{3} / \mathrm{yr}$ & $13.3 \times 10^{9}$ & $66.3 \times 10^{9}$ \\
\hline Carbon Dioxide in Biogas Capture and Reuse, \% & 100 & 100 \\
\hline \multicolumn{3}{|l|}{ Green Methane Sources } \\
\hline Organic Wastes, \% & 0 & 0 \\
\hline Energy Crops-Corn, \% & 0 & 40 \\
\hline
\end{tabular}


Table 10. Cont.

\begin{tabular}{lcc}
\hline \multirow{2}{*}{ Parameter } & \multicolumn{2}{c}{ Year } \\
\cline { 2 - 3 } & $\mathbf{2 0 3 2}$ & $\mathbf{2 0 5 0}$ \\
\hline Green Hydrogen Production, $\mathrm{m}^{3} / \mathrm{yr}$ & $2.3 \times 10^{9}$ & $11.7 \times 10^{9}$ \\
\hline Wind Power for Hydrogen Production, GW & 14 & 72 \\
\hline Wind Power for Electric Propulsion, GW & 3 & 15 \\
\hline Total Wind Power for Heavy Duty PHEVs/HEVs GW & 17 & 89 \\
\hline
\end{tabular}

We may also note that additional wind power generation will be required to supply the electric portion of the energy required for the PHEVs. For light-duty PHEVs this electricity will represent the energy use for the average $73 \%$ of the annual driving distance with electric propulsion. Assuming conservatively that the annual driving of light-duty vehicles will not be reduced over the next thirty years from the present value of about 4.8 trillion kilometers [65], but that the average electric mode efficiency will average $0.23 \mathrm{kWh} / \mathrm{km}$ and will apply to $73 \%$ of the traveled distance, we can calculate the electricity required as:

$$
\begin{aligned}
& \text { Electricity use by light-duty PHEVs: } \\
& 4.8 \times 10^{12} \mathrm{~km} \times 0.73 \times 0.23 \mathrm{kWh} / \mathrm{km}=8.06 \times 101^{11} \mathrm{kWh}
\end{aligned}
$$

The required wind power to generate this amount of electricity will be $307 \mathrm{GW}$. We note that about three-quarters of the required wind power will be dedicated to the production of green hydrogen and one-quarter to the supply of power for the supply of electricity of the vehicles. By way of comparison the alternative of $100 \%$ electric light duty vehicle transportation would require $420 \mathrm{GW}$ of wind power.

Obviously, the huge requirement of wind power to produce additional green methane from carbon dioxide and green hydrogen dictates that the environmentally equally good alternative fuel ( $\mathrm{WE}+\mathrm{GM}+$ ) of not converting the carbon dioxide in the biogas into additional green methane, but rather sequestering it permanently is also presented as Option B in Table 10. In that instance, there would be a need to produce more green methane from energy crops, assuming that all the organic wastes have been used up, while utilizing the same amount of electricity of $307 \mathrm{GW}$ for the electric propulsion. The required wind power to produce the green hydrogen to be part of the RHYME 20-80 fuel is then reduced to $121 \mathrm{GW}$. The alternative option for the supply of the RHYME 20-80, whereby the carbon dioxide in the biogas is permanently sequestered, along with being used as required in the production of other chemicals, is more realistic in terms of the required wind power as well as the associated cost over the next thirty years. In this instance, indicated as B in Table 10, the wind power required for the production of green hydrogen is only a little over one-quarter of the total power required per option A in Table 10. The required green methane to be produced from the current corn energy crops used for ethanol is $52 \times 10^{9} \mathrm{~m}^{3}$ per year and represents $60 \%$ of that crop. We would also like to remark that a lot of marketing emphasis has been placed on BEVs in the past few years. However, the number of PHEVs marketed and sold by all the major automotive manufactures are quietly capturing the market share of electric vehicles in the USA [66]. For example, in 2017, a roughly equal number of BEVs and PHEVs were sold numbering altogether about 200,000 vehicles with a rate of sales increase of about 20 percent annually.

Lastly, we conclude this section by addressing the replacement of diesel fuel for onthe-road heavy-duty vehicles with a RHYME fuel. Once more, we utilize the USA as an example, where the current annual consumption of diesel fuel stands at 170 billion liters, two-thirds of which are used for on-the-road vehicles [67]. The $15 \%$ to $85 \%$ green hydrogen to green methane ratio of the RHYME fuel composition appears to be a better choice for heavy-duty vehicles as already mentioned. In the past two decades, fossil natural gas has gradually been replacing diesel in the operations of transit buses, refuse collection trucks, delivery vans and medium trucks, and heavy-duty trucks as a means to reduce air 
pollution. Moreover, the implementation of renewable natural gas in heavy-duty vehicles is now actively promoted in both the USA and the EU via suitable policies as a means to reduce life cycle carbon dioxide emissions [68]. The carbon index of renewable natural gas, a measure of the carbon dioxide emissions of the fuel, is well below any other fuel, including the use of brown hydrogen in fuel cells and current electricity generation for battery-powered vehicles as shown in Figure 4 [69]. These results are consistent with the analysis presented in this work (Sections 2 and 3). The use of green hydrogen with green methane in a RHYME 15-85 fuel, as already discussed, has the potential to equal and better the life cycle carbon dioxide emissions in heavy-duty vehicles of green methane alone. Moreover, the use of green hydrogen to create the RHYME fuel extends the availability of green natural gas from organic wastes and energy crops resulting from the conversion of wind energy into a green fuel.

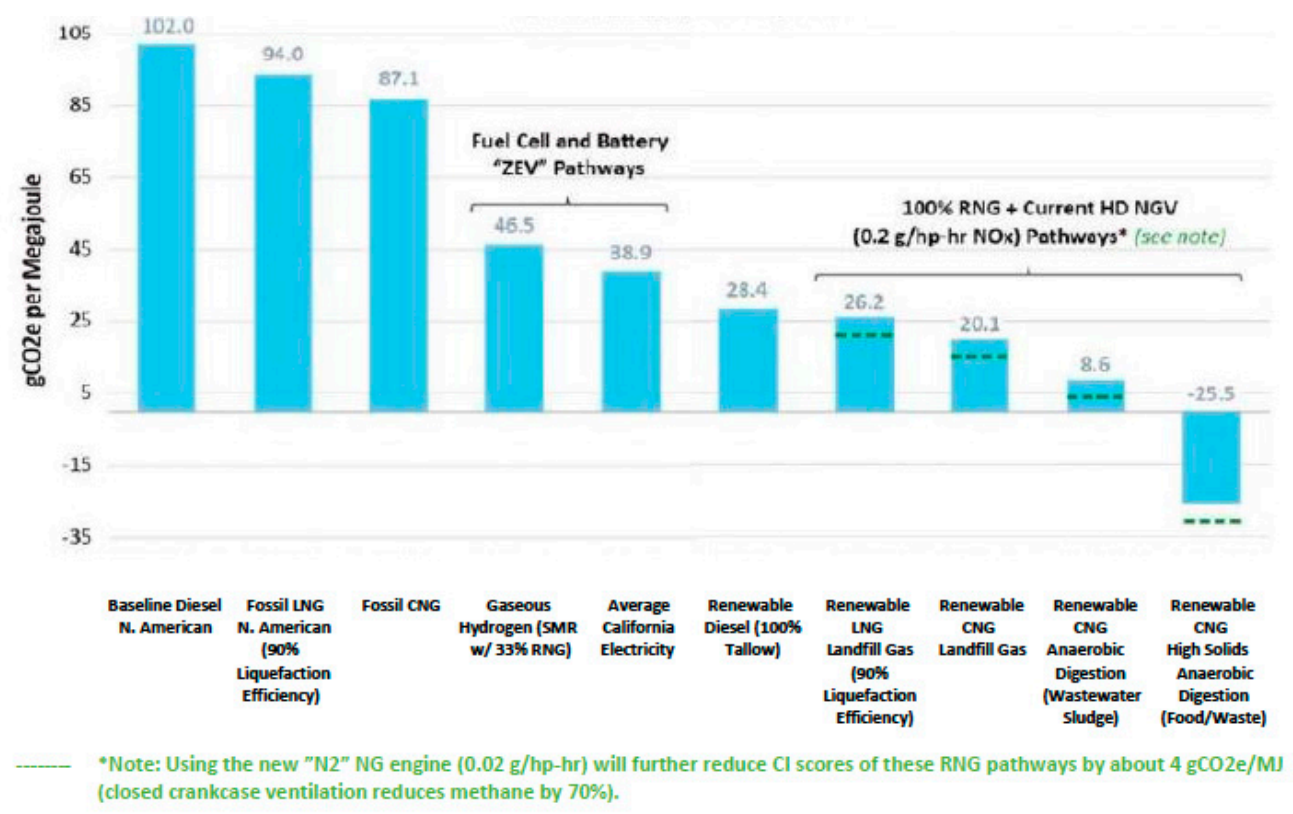

Figure 4. Carbon intensity scores of alternative fuel pathways for heavy-duty vehicles (source: California Air Resources Board 2015, low carbon fuel standard final [69]).

The current use of diesel fuel for on-the-road heavy-duty vehicles in the USA amounts to 112 billion liters per annum. Moreover, the current average fuel consumption of heavyduty vehicles weighted by miles traveled is $3.6 \mathrm{kWh} / \mathrm{km}$. It is projected that fuel consumption may decrease by as much as a factor of three by 2050 with the introduction of fuel-cell-powered HEVs (hybrid electric vehicles) [70]. As we have indicated the use of hydrogen with fuel cell technology is of questionable value due to inherent inefficiencies in the entire process and the cost of the technology itself. Thus, we consider a more modest, but pragmatic, increase in fuel efficiency with an HEV system to $2.4 \mathrm{kWh} / \mathrm{km}$ based on an ICE with electric propulsion and a RHYME 15-85 fuel. The use of a PHEV technology for some of the heavy-duty vehicles that operate exclusively in an urban area is also feasible, although we estimate that a small amount of the fuel can be substituted with electricity, perhaps no more than $5 \%$ of the total. Thus, the 112 billion liters per year of diesel used today for on-the-road vehicles could be reduced to about 75 billion liters per year of diesel by 2050. The replacement of that diesel fuel by 2050 can occur with a net zero or even negative carbon fuel supplied by the combination of mostly (95\%) RHYME 15-85 fuel and some electricity (5\%). Thus, the annual energy consumption of heavy-duty vehicles could amount to 71 billion diesel-fuel-equivalent liters supplied by RHYME 15-85 fuel and 4 billion diesel-equivalent liters of green electricity. We also note that a liter of diesel contains $9.80 \mathrm{kWh}$ of energy, while $1 \mathrm{Nm}^{3}$ of the RHYME $15-85$ fuel contains $8.95 \mathrm{kWh}$ of energy. This, in essence, necessitates by 2050 the annual availability of $11.7 \times 10^{9} \mathrm{~m}^{3}$ of 
green hydrogen and $66.3 \times 10^{9} \mathrm{~m}^{3}$ of green methane. The former will be produced from wind power via water electrolysis and the latter from the anaerobic digestion of energy crops. The implementation of option A per Table 10 leaves available up to $77 \times 10^{9} \mathrm{~m}^{3}$ of green methane from corn, which is more than sufficient to supply the needs for diesel replacement as RHYME 15-85 fuel. On the other hand, the implementation of option B per Table 10, leaves at most $34 \times 10^{9} \mathrm{~m}^{3}$ of green methane available from corn crops. In that case, additional energy crops generating $32.3 \times 10^{9} \mathrm{~m}^{3}$ of green methane per year need to be developed. The most likely scenario for gasoline replacement by RHYME $20-80$ fuel will be somewhere between option A and option B, thereby requiring the development of new energy crops or sources of biomass to be digested to generate an average of $22 \times 10^{9} \mathrm{~m}^{3}$ of green methane annually. This objective can be easily attained given the size of landmass of the country and the variety of climates. In addition, there will be a need for the direct supply of wind electricity amounting to $15 \mathrm{GW}$ of power. We also estimate that by 2032 at most $20 \%$ of the final 2050 replacement of the diesel fuel with more fuel-efficient heavy-duty vehicles operating on RHYME 15-85 fuel and electricity in a HEV and/or PHEV mode may be in place. The results of the analysis of the replacement of the on-the-road use of diesel fuel are also included in Table 10 as option C.

The RHYME fuel will be able to take advantage of the existing natural gas pipeline system in the most industrialized countries for its transportation and distribution from its production sites to the end users. Obviously, the natural gas pipelines transport at the present time fossil natural gas and will do so for a significant time into the future. Consequently, the utilization of the RHYME fuel by an end user will be essentially an accounting scheme akin to the present one of injecting bio-methane or RNG at one point in the system and having an end user at another point, who would pay for that particular product. One may argue that under this delivery arrangement the end user will not receive the exact RHYME fuel. This is strictly true, but the environmental benefit would still apply. An alternative delivery scheme may entail a twostep process as follows: (a) the green methane is injected into the pipeline system at the site of its production as it is done today; and (b) green hydrogen produced at the site of a dedicated RHYME fuel station via electrolysis powered by renewable electricity that the station operator is purchasing through the electric grid, along with green methane that is also purchased from the natural gas pipeline system, is then mixed to the right proportion and sold to customers. As it turns out the RHYME fuel stations can be strategically located in urban areas and along highways to accommodate the fueling needs of owners of PHVEs. Moreover, the RHYME fuel stations do not have to be numerous, given that on the average the owner of a PHEV such as the Prius Prime visits a gasoline fueling station about four times annually [53]. For heavy-duty vehicles, the fueling with diesel occurs typically at the depots where these vehicles are serviced. The RHYME fuel can become available at these depots by the same process as described above. In locations where no natural gas pipelines exist, the RHYME fuel can be transported from the production site to the end user site, i.e., a fueling dispensing station, via truck. This practice has been around for the transport of natural gas and can be extended for the transport of the RHYME fuel, as well in specialized situations.

\section{Conclusions}

The results of the preceding analysis indicate that the permanent establishment of green hydrogen into the energy sector would require the concurrent use of green methane as a means of facilitating this introduction at least in the early stages of that realization over the next 10 to 30 years. The reasons have already been discussed and are summarized here as well:

(a) Green hydrogen is not an energy source, but an energy carrier, while green methane is an energy source;

(b) Converting other renewable energy sources such as wind power or even biomethane so that green hydrogen becomes a universal energy source is noncompetitive economically, is overall suboptimal and does not provide the best environmental results; 
(c) The green hydrogen-green methane combination combines the best aspects of both of these fuels, namely, the efficiency of combustion for a higher fuel efficiency in vehicles, the reduction in carbon dioxide emissions to even a negative level and a high energy density for a feasible storage in a limited space such as on board vehicles;

(d) It allows the utilization of the existing natural gas transmission and distribution pipeline system without major modifications, thereby reducing substantially the need of, and the cost for new delivery infrastructure;

(e) The road transportation sector can attain a net zero carbon status in the near future by implementing currently available, cost-effective technology for light-duty as well as heavy-duty vehicles.

A possible concern associated with the use of green methane is the issue of fugitive emissions. Methane is a potent greenhouse gas and the production and distribution of natural gas is known to result in atmospheric leaks [14]. Green methane is produced under anaerobic conditions that are critical for the success of the process. Consequently, the leakage of green methane at its production sites cannot occur unless a failure in the process takes place that is then remedied for the operation to continue. Leaks in the transmission and distribution system can occur and do occur, but they can be tracked down easily with existing space satellites and be repaired [71,72].

Another possible concern is that the distribution of renewable energy is not uniform around the globe. Consequently, some regions or countries may be more favorably endowed with wind, solar or biomass, such as, for example, the USA. In addition, other counties may have a large industrial base for manufacturing, advanced technology and a highly developed infrastructure such as a power grid and a natural gas pipeline system, such as, for example, the already mentioned cases of the USA and Germany. It would seem then that such countries or regions are favorably predisposed to develop the production and utilization of green hydrogen along with green methane for the RHYME fuel and the associated transportation technology as we have already discussed. Obviously, relevant regional and country policies need to be developed to address such dissimilarities. It is suggested, for example, that in the region of Southeast Europe a diversified supply of natural gas and a network of natural gas pipelines be developed as a precursor to the introduction and utilization of green hydrogen [73]. Moreover, on the broader global state of the introduction of green hydrogen, a recent study concludes that the aforementioned disparities do not pose a risk for the less fortunate in this regard regions, because there will be regional trade-offs such as, for example, between the EU and countries of the African Union to level the playing field [74].

The implementation of the proposed RHYME fuel in order to introduce green hydrogen into the energy sector, and more specifically in road transportation, would require the involvement of stakeholders in both the public and private sectors. The public sector would consist of the local, state and federal governments through appropriate agencies or departments. The private sector would involve energy companies, electric and natural gas utilities, automotive manufacturers and financing institutions at a minimum. A strategy must be developed to achieve the objective at hand, namely, the introduction of green hydrogen into the energy sector of a country or even a group of contiguous countries. Such a strategy is also referred to as a "roadmap" or more appropriately as a "technology roadmap" because it pertains to the introduction of green hydrogen [75]. The International Energy Agency (IEA) defines a technology roadmap as "a dynamic set of technical, policy, legal, financial, market, and organizational requirements identified by all stakeholders involved in its development". A number of scenarios have been presented in this work to describe specific outcomes in terms of the implementation of green hydrogen through the concept of the RHYME fuels. These scenarios are hypothetical, but internally consistent, attempt to establish the desired goals by certain dates and can be used to develop the relevant technological roadmap. The roadmap must also include the necessary steps to be taken in order to reach the intended goals presented in the scenarios, with the participation of 
all key shareholders. Creating the roadmap for the implementation of the green hydrogen economy is obviously outside the purview of this work.

Funding: This research was supported in its entirety internally and received no external funding.

Acknowledgments: The author would like to acknowledge the fruitful comments of the anonymous reviewers of this article.

Conflicts of Interest: The author declares no conflict of interest.

\section{Abbreviations}

$\begin{array}{ll}\text { AD } & \text { Anaerobic digestion } \\ \text { BEV } & \text { Battery electric vehicle } \\ \text { CGV } & \text { Conventional gasoline vehicle } \\ \text { CV } & \text { Conventional vehicle identical to CGV except using besides gasoline diesel or } \\ \text { FCEV } & \text { natural gas } \\ \text { HEV } & \text { Fuel cell electric vehicle } \\ \text { GH } & \text { Hybrid electric vehicle } \\ \text { GM } & \text { Green hydrogen } \\ \text { GM+ } & \text { Green methane or biomethane } \\ \text { GM + H } & \text { Green methane with reuse of the carbon dioxide in the biogas with GH to } \\ \text { IEC } & \text { produce GM } \\ \text { PHEV } & \text { Internal combustion engine } \\ \text { RHYME } & \text { Plug-in hybrid electric vehicle } \\ \text { RNG } & \text { Renewable (green) hydrogen and renewable (green) methane mixture } \\ \text { WE } & \text { Renewable natural gas, another term for GM } \\ \text { WE }+ \text { GM+ } & \text { Wind energy } \\ \text { WE + GM + H } & \text { Equivalent to GM or GM+ and emphasizing the use of WE for its production }\end{array}$

\section{References}

1. Hoffmann, P. Tomorrow's ENERGY — Hydrogen, Fuel Cells and the Prospect for A Cleaner Planet; The MIT Press: Cambridge, MA, USA, 2002.

2. Bockris, J. Energy: The Solar-Hydrogen Alternative; Halstead Press: Sydney, Australia, 1975.

3. Bermudez, J.M.; Hannula, I. Hydrogen-More Efforts Needed, IEA Tracking Report. November 2021. Available online: https:/ / www.iea.org/reports/hydrogen (accessed on 10 November 2021).

4. Sun, P.; Young, B.; Elgowainy, A.; Lu, Z.; Wang, M.; Morelli, B.; Hawkins, T. Criteria Air Pollutants and Greenhouse Gas Emissions from Hydrogen Production in U.S. Steam Methane Reforming Facilities. Environ. Sci. Tech. 2019, 53, 7103-7113.

5. Bartlett, J.; Krupnick, A. Decarbonized Hydrogen in the US Power and Industrial Sectors: Identifying and Incentivizing Opportunities to Lower Emissions, Report 20-25, Resources for the Future. 2020. Available online: https:/ /rff.org/documents / RFF_Report_20-25_Decarbonized_Hydrogen.pdf (accessed on 3 November 2021).

6. T-Raiss, A.; Clock, D.L. Hydrogen: Automotive fuel of the Future. IEEE Power Energy Mag. 2004, 2, 40-45. [CrossRef]

7. Global CCS Institute. Global Status of CCS; The Global CCS Institute: Melbourne, Australia, 2020.

8. Collodi, G.; Azzaro, G.; Ferrari, N.; Santos, S. Techno-economic Evaluation of Deploying CCS in SMR Based Merchant $\mathrm{H}_{2}$ Production with NG as Feedstock and Fuel. Energy Proc. 2017, 114, 2690-2712. [CrossRef]

9. Government of Alberta. Quest $\mathrm{CO}_{2}$ Capture Ratio Performance, Quest Carbon Capture Project and Storage (CCS) Project. 2020. Available online: https:/ / open.alberta.ca/dataset/f74375f3-3c73-4b9c-af2b-ef44e59b7890/resource/c36cf890-3b27-4e7e-b95b3370cd0d917d/download/energy-quest-co2-capture-ratio-performance-2019.pdf (accessed on 17 November 2021).

10. Intergovernmental Panel on Climate Change. Carbon Dioxide Capture and Storage, IPCC. 2005. Available online: https: ///www.ipcc.ch./report/carbon-dioxide-capture-and-storage/ (accessed on 18 November 2021).

11. Masoudi Soltani, S.; Lahiri, A.; Bahzad, H.; Clough, P. Sorption-enhanced Steam Methane Reforming for Combined $\mathrm{CO}_{2}$ Capture and Hydrogen Production: A State-of-the-Art Review. Carbon Capture Sci. Technol. 2021, 1, 100003. Available online: https:/ / reader.elsvier.com/reader/sd/pii/S2772656821000038/token? (accessed on 8 November 2021).

12. Jacobson, M.Z. Review of Solutions to Global Warming, Air Pollution and Energy Security. Energy Environ. Sci. 2009, 2, 148-173. [CrossRef]

13. Sgouridis, S.; Carbajales-Dale, M.; Csala, D.; Bandi, U. Comparative Net Energy Analysis and Storage. Nat. Energy 2019, 4, 456-465. [CrossRef] 
14. Howarth, R.W.; Jacobson, M.Z. How Green is Blue Hydrogen? Energy Sci. Eng. 2021, 9, 1676-1687. [CrossRef]

15. Tomic, B. Offshore Wind: Things are Getting Bigger, Offshore Engineer. 2021. Available online: www.oedigital.com (accessed on 10 November 2021).

16. The $15 \mathrm{MW}$ Wind Turbines Have A Height of about $250 \mathrm{~m}$ and A Rotor Diameter of about $220 \mathrm{~m}$. The Power Output of A Wind Turbine Is Proportional to the Swept Area of the Rotor, which is in turn Proportional to the Square of Its Diameter. In 1919 the German Physicist Albert Betz Derived and then Published in 1926 in His Wind Energie the Proposition Now Known as "Betz Law." This Law States That at Most Only 16/27 or 59.259\% of the Wind Kinetic Energy Crossing the Swept Area of the Rotor Can Be Captured. In Practice Today Anywhere from 35\% to 45\% Can Be Captured in A Wind Turbine. THUS, A Wind Turbine with Today's Technology and with A Height of $480 \mathrm{~m}$ and A Rotor Diameter of $450 \mathrm{~m}$ Would Have An Output of about $63 \mathrm{MW}$. Assuming then the Maximum 59.259\% Efficiency vs. the Current One of 35\% to $45 \%$ is Possible, We Could Obtain A Power Output Anywhere from 83 MW to 107 MW, Which is Consistent with Honeff's Claim in the 1930s. See Also: Proof of Betz's Law. Available online: www.dr $\backslash \mathrm{T} 1 \backslash$ omst $\backslash \mathrm{T} 1 \backslash$ orre.dk/wp-content/wind/miller/windpower\%20web/en/stat/betzpro.htm (accessed on 16 November 2021).

17. Schmidt, O.; Gambhir, A.; Staffel, L.; Wahkes, A.; Nelson, J.; Few, S. Future Cost and Performance of Water Electrolysis: An Expert Elicitation Study. Int. J. Hydrog. Energy 2017, 42, 30470-30492. [CrossRef]

18. NEL. Hydrogen Technology Innovations: Industry Transport Energy, Company Brochure. 2020. Available online: www. nelhydrogen.com (accessed on 11 November 2021).

19. Helman, C. How Green is Wind Power, Really? A New Report Tallies Up the Carbon Cost of Renewables, Forbes. 28 April 2021. Available online: https://www.forbes.com/sites/christopherhelman/2021/04/28/how-green-is-wind-power (accessed on 16 November 2021).

20. Liebreich, M. Separating Hype from Hydrogen-Part One: The Supply Side, BloombergNEF, 8 October 2020. Available online: https:/ / about.bnef.com/blog/liebreich-separating-hype-from-hydrogen-part-one-the-supply-side (accessed on 19 November 2021).

21. EIA. Natural Gas Statistics, Energy Information Administration, US Department of Energy. 2021. Available online: https: //www.eia.gov/dnav/ng/NG_PRI_SUM_DCU_NUS_M.htm (accessed on 20 November 2021).

22. Kost, C. DE2018_Studie: Stromgestehungskosten erneuerbare Energien (März 2018). Available online: https://www.ise. fraunhofer.de/de/veroeffentlichungen/studien/studie-stromgestehungskosten-erneuerbare-energien.html (accessed on 20 November 2021).

23. Kost, C. DE2021_Studie: Stromgestehungskosten erneuerbare Energien (Juni 2021). Available online: https:/ /www.ise.fraunhofer.de/ de/veroeffentlichungen/studien/studie-stromgestehungskosten-erneuerbare-energien.html (accessed on 20 November 2021).

24. IRENA. Majority of New Renwables Undercut Cheapest Fossil Fules on Cost, International Renewable Energy Association. 2020. Available online: https://www.irena.org/-/media/Files/IRENA/Agency/Publication/2021/Jun/IRENA_Power_Generation_ Costs_2020.pdf (accessed on 20 November 2021).

25. EIA. Levelized Costs of New Generation Resources in the Annual Energy Outlook 2022, US Energy Information Administration, February 2021. Available online: https:/ / www.eia.gov/outlooks/aeo/pdf/electricity_generation.pdf (accessed on 20 November 2021).

26. Jaganmohan, M. Global Hydrogen Electrolyzer Projects in Pipeline 2020 by Expected Capacity, Statista 28 January 2021. Available online: https:/ / www.statista.com/statistics/1179559/hydrogen-electrolyzers-by-capacity-worldwide-location (accessed on 20 November 2021).

27. Ingersoll, J. Bio-Methane: The Alternative Renewable Fuel for Transportation, Xlibris Corporation. 2010. Available online: www.xlibris.com (accessed on 25 November 2021).

28. IRENA. Biogas for Road Vehicles-Technology Brief, International Renewable Energy Agency, Original Report Published in March 2017 and Updated in March 2018, ISBN 978-92-9260-060-0. 2018. Available online: www.irean.com (accessed on 9 November 2021).

29. Carbon Dioxide Is A Versatile Material with A Multitude of Industrial Applications such as in Food, Refrigeration, Semiconductors, Welding, Fire-Fighting, Chemicals Manufacturing to Name A Few. See Also "Carbon Dioxide" Entry in Wikipedia at. Available online: https:/ / en.wikipedia.org/wiki/Carbon_dioxide (accessed on 21 November 2021).

30. Strubing, D.; Huben, B.; Lebuhn, M.; Drewes, J.E. High Performance Biological Methanization in a Thermophilic Anaerobic Trickle Bed Reactor. Bioresour. Technol. 2017, 245, 1176-1183. [CrossRef] [PubMed]

31. Kougias, B.; Treu, L.; Benavente, D.P.; Boe, K.; Campanaro, S.; Angelidaki, I. Ex-situ Biogas Upgrading and Enhancement in Different Reactor Systems. Bioresour. Technol. 2017, 255, 429-437. [CrossRef] [PubMed]

32. Electroahaea, G.M.B.H. 82152 Planegg, Bavaria, Germany. Available online: www.elecrochaea.com (accessed on 27 November 2021)

33. Ingersoll, J.G. Thermophilic Co-Fermentation of Wood Wastes and High in Nitrogen Animal Manures into Bio-Methane with the Aid of Fungi and Its Potential in the USA. Energies 2020, 13, 4257. [CrossRef]

34. Onyeaka, H.; Miri, T.; Obileke, K.; Hart, A.; Anumudu, C. Minimizing Carbon Footprint via Microalgae as a Biological Capture. Carbon Capture Sci. Technol. 2012, 1, 100007. Available online: www.elsevier.com/locate/ccst (accessed on 8 November 2021). [CrossRef]

35. Brightbiomethane. Membrane Biogas Upgrading Systems with $\mathrm{CO}_{2}$ Recovery and Liquefaction, Bright Biomethane BV, The Netherlands. 2021. Available online: www.brighbiometahne.com (accessed on 4 November 2021). 
36. EBA. The Contribution of the Biogas and Biomethane Industries to Medium-term Greenhouse Gas Reduction Targets and Climate Neutrality by 2050, EBA-European Biogas Association, Background Paper, Brussels, Belgium, April 2020. Available online: https:/ / www.gasworld.com/biomethane-for-a-negative-carbon-footprint/2018977.article (accessed on 8 November 2021).

37. EBA. Smart $\mathrm{CO}_{2}$ Standards for Negative Emissions Mobility, European Biogas Association, Brussels, Belgium, June 2021. Available online: https://www.europeanbiogas.eu/wp-content/uploads/2021/06/SMART-CO2-STANDARDS-FORNEGATIVE-EMISSIONS-MOBILITY.pdf (accessed on 5 November 2021).

38. Baldino, C.; Pavlenko, N.; Searle, S.; Christensen, A. The Potential for Low-Carbon Renewable Methane in Heating, Power, and Transport in the European Union, Working Paper 2017-26, The International Council on Clean Transportation (ICCT), October 2018. Available online: https:/ / theicct.org/sites/default/files/publications/Renewable_Gas_EU-28_20181016.pdf (accessed on 22 November 2021).

39. Øi, L.E.; Eldrup, N.; Adhikari, U.; Bentsen, M.H.; Badalge, J.L.; Yang, S. Simulation and Cost Comparison of $\mathrm{CO}_{2}$ Liquefaction. Energy Procedia 2016, 86, 500-510. [CrossRef]

40. de Miranda, P.E.V. Hydrogen Energy: Sustainable and Perennial, Science and Engineering of Hydrogen-Based Technologies; de Miranda, P.E.V., Ed.; Academic Press-An Imprint of Elsevier: London, UK, 2019.

41. Williams, L.O. Hydrogen Power-An Introduction to Hydrogen Energy and its Applications; Pergamon Press: Oxford, UK, 1980.

42. Liebreich, M. Separating Hype from Hydrogen—Part Two: The Demand Side, BloombergNEF, 16 October 2020. Available online: https:/ / about.bnef.com/blog/liebreich-separating-hype-from-hydrogen-part-one-the-supply-side (accessed on 19 November 2021).

43. Madeddu, S.; Ueckerdt, F.; Pehl, M.; Peterseim, J.; Lord, M.; Kumar, K.A.; Kruger, C.; Luderer, G. The $\mathrm{CO}_{2}$ Reduction Potential for the European Industry via Direct Electrification of Heat Supply (Power-to-Heat). Environ. Res. Lett. 2020, 15, 12404. [CrossRef]

44. Carmo, M.; Stolten, D. Energy Storage Using Hydrogen Produced from Excess Renewable Electicity: Power to Hydrogen, Science and Engineering of Hydrogen-Based Technologies; de Miranda, P.E.V., Ed.; Academic Press-An Imprint of Elsevier: London, UK, 2019.

45. Kalya, D. Unearthed Today: Why Oil Companies Want You to Love Hydrogen, Unearthed, Amsterdam, The Netherlands. 2020. Available online: https: / unerathed.greenpeace.org/2020/12/08//unearthed-today-why-oil-companies-want-you-to-lovehydrogen/ (accessed on 19 November 2021).

46. Coralli, A.; Sarruf, B.J.M.; de Miranda, P.E.V.; Osmieri, L.; Specchia, S.; Minh, N.Q. Fuel Cells in Science and Engineering of Hydrogen-Based Technologies; de Miranda, P.E.V., Ed.; Academic Press-An Imprint of Elsevier: London, UK, 2019.

47. EIA. U.S. Energy-Related Carbon Dioxide Emissions 2019, U.S. Energy Information Administration, September 2020, Washington, DC, 2020. Available online: https:/ / www.eia.gov/environment/emissions/carbon/ (accessed on 26 November 2021).

48. Hausfather, Z. Factcheck: How Electric Vehicles Help to Tackle Climate Change, Carbon Brief: Clear Climate, Initially Published 13 May 2019, Revised 2 July 2020. 2019. Available online: https://www.carbonbrief.org/factcheck-how-electric-vehicles-help-totackle-climate-change (accessed on 23 November 2021).

49. Hall, D.; Lutsey, N. Effects of Battery Manufacturing on Electric Vehicle Life-Cycle Greenhouse Gas Emissions, International Council on Clean Transportation, February 2018. Available online: https:/ theicct.org/sites/default/files/publications/EV-lifecycle-GHG_ICCT-Briefing_09022018_vF.pdf (accessed on 28 November 2021).

50. Uchida, H.; Harada, M.R. Utilization of Hydrogen Energy, Science and Engineering of Hydrogen-Based Technologies; de Miranda, P.E.V., Ed.; Academic Press-An Imprint of Elsevier: London, UK, 2019.

51. Carlier, M. Daily Miles of Travel per Driver in the United States between 2001 and 2017, Statista. 2021. Available online: https:/ / www.statista.com/statistics/1007157/us-daily-miles-per-driver/ (accessed on 30 November 2021).

52. US DOE \& US EPA. The Official US Government Source for Fuel Economy Information. 2021. Available online: https://www. fueleconomy.gov/feg/findacar.shtml (accessed on 1 December 2021).

53. Smart, J.; Powell, W.; Schey, S. Extended Range Electric Vehicle Driving and Charging Behavior Observed Early in the EV Project; SAE International: Warrendale, PA, USA, 2013. [CrossRef]

54. Le Fevre, C. A Review of Prospects for Natural Gas as a Fuel in Road Transport, Energy Insight: 50, April 2019, The Oxford Institute for Energy Studies. 2019. Available online: https:/ / www.oxfordenergy.org/publications / (accessed on 5 December 2021).

55. Bioenergy International. RNG Surpasses NG Accounting for 53 Percent of US On-road NGV Fuel in 2020, Bioenergy International, 16 April 2021. Available online: https:/ / bioenenrginternational.com/markets-financing/rng-surpassed-ng-accounting-fo-53 -percent-of-us-on-road-ngv-fuel-in-2020 (accessed on 31 October 2021).

56. Hythane Company. Hythane-Tomorrow's Low Cost, Low Emission Fuel Today, Eden Energy Ltd. 2016. Available online: https://www.edeninnovations.com/wp-content/uploads/2016/10/Presentation22.pdf (accessed on 5 December 2021).

57. Anstrom, J.R. Hydrogen as a Fuel in Transportation, in Advances in Hydrogen Production, Storage and Distribution, HythaneAn Overview, ScienceDirect.com, Elsevier. 2014. Available online: https:/ / www.sciencedirect.com/science/article/pii/B9780857 097682500171 (accessed on 16 October 2021).

58. Anstrom, J.R.; Collier, K. Blended Hydrogen-Natural Gas-Fueled Internal Combustion Engines and Fueling Infrastructure, in Compendium of Hydrogen Energy, Hythane-An Overview, ScienceDirect.com, Elsevier. 2016. Available online: https://www. sciencedirect.com/science/article/pii/B9781782423638000086 (accessed on 16 October 2021).

59. Genovese, A.; Villante, C. Environmental Analysis of Hydrogen-Methane Blends for Transportation, in Membranes for Clean and Renewable Power Applications, Hythane-An Overview, ScienceDirect.com, Elsevier. 2014. Available online: https://www. sciencedirect.com/science/article/pii/B9780857095459500082 (accessed on 16 October 2021). 
60. Molina, S.; Gomez-Soriano, J.; Olcina-Girona, M. New Combustion Modelling Approach for Methane-=Hydrogen Fueled Engines Using Machine Learning and Engine Visualization. Energies 2021, 14, 6732. [CrossRef]

61. Lee, T.H.; Linden, H.R.; Dreyfus, D.A.; Vasko, T. The Methane Age; Kluwer Academic Publishers, Dordrecht, NL and International Institute for Applied Systems Analysis: Laxenburg, Austria, 1988.

62. Kolb, R.W. The Natural Gas Revolution-At the Pivot of the World's Energy Future; Pearson: Upper Saddle River, NJ, USA, 2014.

63. EIA. U.S. Dry Natural Gas Production, U.S. Energy Information Administration. 2021. Available online: https://www.eia.gov/ dnav/ng/hist/n9070us2A.htm (accessed on 7 December 2021).

64. EIA. Gasoline Explained: Use of Gasoline, U.S. Energy Information Administration. 2021. Available online: https://www.eia. gov / energyexplained/gasoline/use-of-gasoline.php (accessed on 9 December 2021).

65. FHWA. Highway Statistics 2016: Annual Vehicle Distance Traveled in Miles and Related Data-2016. U.S. Federal Highway Administration December 2017. Available online: https://www.fhwa.dot.gov/policyinformation/statistics/2016/vm1.cfm (accessed on 11 December 2021).

66. Gohlke, D.; Zhou, Y. Impacts of Electrification of Light Duty Vehicles in the United States 2012-2017, Argonne National Laboratory, Report ANL/ESD-18-1, January 2018. Available online: https:/ / publications.anl.gov/anlpubs/2018/01/141595.pdf (accessed on 26 November 2021).

67. EIA. Diesel Fuel Explained: The Use of Diesel, U.S. Energy Information Administration. 2021. Available online: https://www.eia. gov / energyexplained/diesel-fuel/use-of-diesel.php (accessed on 9 December 2021).

68. Biogas World. Renewable Natural Gas for Heavy Duty Vehicles: Why Not?, Biogas World, 5 February 2019. Available online: https:/ / www.biogasworld.com/news/renewable-natural-gas-heavy-duty-vehicles/ (accessed on 12 December 2021).

69. CARB. LCFS Regulation, California Air Resources Board, 15 November 2015. Available online: https:/ / ww2.arb.ca.gov / ourwork/programs/low-carbon-fuel-standard/lcfs-regulation (accessed on 12 December 2021).

70. Marcinoski, J.; Vijayogopal, R.; Adams, J.; James, B.; Kopasz, J.; Ahluwalla, R. DOE Advanced Truck Technologies—Electrified Powertrain Roadmap Technical Targets, U.S. Department of Energy. 2019. Available online: https://www.hydrogen.energy.gov/ pdfs/19006_hydrogen_class8_long_haul_truck_targets.pdf (accessed on 12 December 2021).

71. ESA. Mapping Methane Emissions on a Global Scale, The European Space Agency, 4 May 2020. Available online: https://www.esa. int/Applications/Observing_the_Earth/Copernicus/Sentinel-5P/Mapping_methane_emissions_on_a_global_scale (accessed on 13 December 2021).

72. ESA. Mapping High Resolution Methane Emissions from Space, The European Space Agency, 14 December 2020. Available online: https:/ / www.esa.int/Applications/Observing_the_Earth/Copernicus/Sentinel-5P/Mapping_high-resolution_methane_ emissions_from_space (accessed on 13 December 2021).

73. Sadik-Zada, E.R.; Gutto, A. Energy Security Pathways in South East Europe: Diversification of the Natural Gas Supplies, Energy Transition and Energy Futures. In From Economic to Energy Transition: Energy, Climate and the Environment; Musik, M., Oravcova, V., Eds.; Palgrave Macmillan: Cham, Swizterland, 2021. [CrossRef]

74. Sadik-Zada, E.R. Political Economy of Green Hydrogen Rollout: A Global Perspective. Sustainability 2021, 13, 13464. [CrossRef]

75. Hart, D. Roadmapping, Science and Engineering of Hydrogen-Based Technologies; de Miranda, P.E.V., Ed.; Academic Press-An Imprint of Elsevier: London, UK, 2019. 